\title{
The Hydropedograph Toolbox and its application
}

\section{B. Graham ${ }^{1}$ and H. S. Lin $^{2}$}

${ }^{1}$ Hetch Hetchy Water and Power, Moccasin, CA 95347, USA

${ }^{2}$ Department of Ecosystem Science and Management, The Pennsylvania State University, University Park, PA 16802, USA

Received: 19 November 2012 - Accepted: 24 November 2012

- Published: 21 December 2012

Correspondence to: H. S. Lin (henrylin@psu.edu)

Published by Copernicus Publications on behalf of the European Geosciences Union.
The Hydropedograph Toolbox and its application

C. B. Graham and H. S. Lin

Title Page
Abstract

Conclusions

Tables

14

4

Back
Introduction

References

Figures

$\rightarrow$

Close
Full Screen / Esc

Printer-friendly Version

Interactive Discussion 


\section{Abstract}

The Hydropedograph Toolbox has been developed to provide a set of standardized tools for analyzing soil moisture time series in an efficient and consistent manner. This toolbox contains various modules that permit the exploration and visualization of 5 key soil hydrological parameters and processes using multi-depth real-time soil moisture monitoring datasets. This includes statistical summary, soil water release curve, preferential flow occurrence, hydraulic redistribution, and the relationship between soil moisture and soil temperature. After describing this toolbox, this paper demonstrates the utility of this toolbox in a case study from the Shale Hills Critical Zone Observatory in USA. The case study illustrates the topographic impacts on soil moisture dynamics along a hillslope transect, and quantifies the frequency of the occurrence of preferential flow, diel fluxes of water, and seasonal storage dynamics. It is expected that such a toolbox, with continued enhancements in the future and wide applications across diverse landscapes, can facilitate the advancement of comparative hydrology and hydropedology.

\section{Introduction}

Soil moisture is a key component of the terrestrial water balance, and the temporal patterns of soil moisture response to precipitation is a key control on the hydrologic cycle, runoff and erosion, stream and groundwater flow, vegetation viability and distribution, soil weathering, nutrient cycling, contaminant transport, landslide occurrence, and other landscape processes. However, the temporal and spatial patterns of soil moisture remain difficult to predict. To better understand the temporal and spatial distributions of soil moisture, it is increasingly measured with large numbers of soil moisture sensors.

High density soil moisture monitoring networks have become more common globally (e.g., Bogena et al., 2010; Dorigo et al., 2011). For example, at the Shale Hills Critical
HESSD

9, 14231-14271, 2012

The Hydropedograph

Toolbox and its application

C. B. Graham and H. S. Lin

Title Page

Abstract

Introduction

Conclusions

Tables

References

Figures

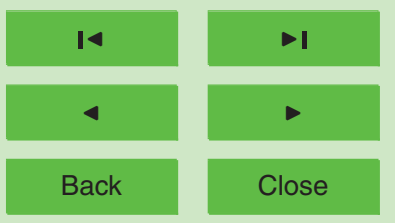

Full Screen / Esc

Printer-friendly Version

Interactive Discussion 
Zone Observatory (SHCZO) in central Pennsylvania, USA, there are now 3 to 10 soil moisture probes recording every $10 \mathrm{~min}$ in 35 soil profiles across the 7.9-ha forested catchment (Fig. 1). At the Southern Sierra Critical Zone Observatory in southern California, 24 soil moisture sensors were installed in 6 soil profiles surrounding a single 5 White fir and were used to analyze for response to snowmelt and precipitation events (Bales et al., 2011). At the 33-ha headwater catchment in the Sierra Nevada foothills of Northern California, soil moisture has been monitored at four depths in 100 soil profiles to understand water storage and streamflow regulation by soils (Swarowsky et al., 2011). As equipment prices continue to fall and the interest in soil moisture storage 10 and flux dynamics continues to rise, the incidence of high spatial density, high temporal precision soil moisture monitoring datasets will continue to grow rapidly.

This increase in high density of soil moisture monitoring will only result in a greater increase in the data flood coming out of these highly instrumented field sites. At the SHCZO alone, there are over 200 soil moisture sensors in 35 instrumented sites, all 15 recording at 10 min intervals. This results in 52560 measurements per year per sensor, and over 10 million soil moisture measurement data points annually. Clearly, this is a significant increase in the amount of data than what was possible even $12 \mathrm{yr}$ ago, when the set of 8639 soil moisture measurements at the Tarrawarra Watershed in Australia (a significant contribution to our understanding of soil moisture patterns) was viewed as a notably large data set (Western et al., 1999a and b).

A significant result of this flood of data is the concern that the data are being underutilized. In the field of hydrology, where similar time series data (i.e., streamflow and precipitation) has been a mainstay for over $100 \mathrm{yr}$, a number of tools have been developed for analysis, including recession analyses (Vitvar et al., 2002), hydrograph separation (Hewlett and Hibbert, 1967; Sklash and Farvolden, 1979), diel signal analyses (Bond et al., 2002; Graham et al., 2012), probability distributions and flood frequency estimations (Dingman, 2002), snow melt and evapotranspiration timing patterns (Troxell, 1936; Lundquist and Cayan, 2002), and many others. In soil science, it is less clear what key graphical analyses of soil moisture time series are embraced by the

\section{HESSD}

$9,14231-14271,2012$

\section{The Hydropedograph \\ Toolbox and its application}

C. B. Graham and H. S. Lin

Title Page

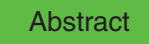

Introduction

Conclusions

Tables

References

Figures

14

4

Back

Full Screen / Esc

Printer-friendly Version

Interactive Discussion 
community. These analyses should be part of any initial investigation of soil moisture patterns and processes, especially when dealing with large datasets from sensor networks.

In this paper, we demonstrate a MATLAB-based toolbox, called the Hydropedograph

5 Toolbox, for analysis of time series of soil moisture profiles. We have identified five core components of soil moisture analysis based on real-time high temporal density datasets: (1) time series statistical summaries, (2) moisture release curves, (3) preferential flow identification, (4) diel signals in soil moisture, and (5) soil moisture and temperature relationships. We acknowledge that this initial version of the toolbox is not 10 yet exhaustive, but envision it to be an open source program allowing for continuing expansion and incorporation of new methods and procedures. This toolbox has currently incorporated key analyses performed in our work analyzing soil moisture temporal and spatial patterns at the SHCZO.

To demonstrate the utility of the Hydropedograph Toolbox, all modules were run for 15 one transect of soil moisture monitoring sites in a topographic gradient at the SHCZO using one full year of real-time monitoring data. This case study addresses a key area of uncertainty in hydrology, i.e., the effect of topographic position on soil moisture patterns. Western et al. (1999a) have shown that during wet conditions, soil moisture is a function of topographic position with high levels of organization. During wet conditions soil moisture tends to increase with increasing upslope contributing area. The topographic wetness index (TWI) of Beven and Kirkby (1979) was based on the observation that the two dominant controls on soil wetness are slope and upslope contributing area, as expressed by the function $\mathrm{TWI}=\ln (a / \tan \beta)$, where $a$ is the area draining through a point from upslope and $\tan \beta$ is the local slope angle. While these findings are generally accepted in the catchment hydrology community, how these observations are expressed in terms of local time series of soil moisture remains unclear, since soil moisture dynamics are often more complex than simple topographical control (because of additional factors involved, such as soil type and vegetation; see Zhu and Lin, 2011; Takagi and Lin, 2012). Here we demonstrate the utility of the Hydropedograph Toolbox
HESSD

$9,14231-14271,2012$

\section{The Hydropedograph \\ Toolbox and its application}

C. B. Graham and H. S. Lin

Title Page

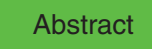

Introduction

Conclusions

Tables

References

Figures

14

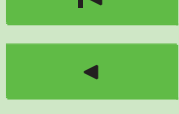

$\rightarrow$ I

Back

Close

\section{4}


in providing more insights into the impacts of topography and other factors on soil moisture dynamics and the related underlying processes.

\section{HESSD}

$9,14231-14271,2012$

\section{The Hydropedograph Toolbox}

The goal of the Hydropedograph Toolbox is to provide a set of standardized tools for 5 analyzing soil moisture time series in a thorough and consistent manner. The toolbox is presented as a set of MATLAB-based Graphical User Interfaces (GUIs), and is designed to be open source. The key modules of this toolbox at the present time include (Fig. 2): (1) summary plots, (2) moisture release curves, (3) preferential flow, (4) diel signals in soil moisture, and (5) soil moisture and temperature relationships. The goal and methodology of each of these modules are described below in this section. Each module is designed to analyze a soil profile consisting of synchronous soil moisture measurements at multiple depths. Required data include the time series of soil moisture of adequate temporal resolution and duration but with multiple depths within a soil profile. For the moisture release module, collocated time series of matric potential

are also needed for each soil depth monitored, while for the soil moisture and temperature module, collocated time series of soil temperature are also needed for each soil depth monitored. The preferential flow module optionally will accept a time series of precipitation, while the diel signals module can accept an optional time series of evapotranspiration.

Input data are accepted in many formats, including Excel spreadsheets, ASCII files, and csv files. Formatted files with the soil depths of each sensor in the header row allow for automatic depth parameterization, or sensor depths can be input directly into the toolbox GUI (Fig. 2).

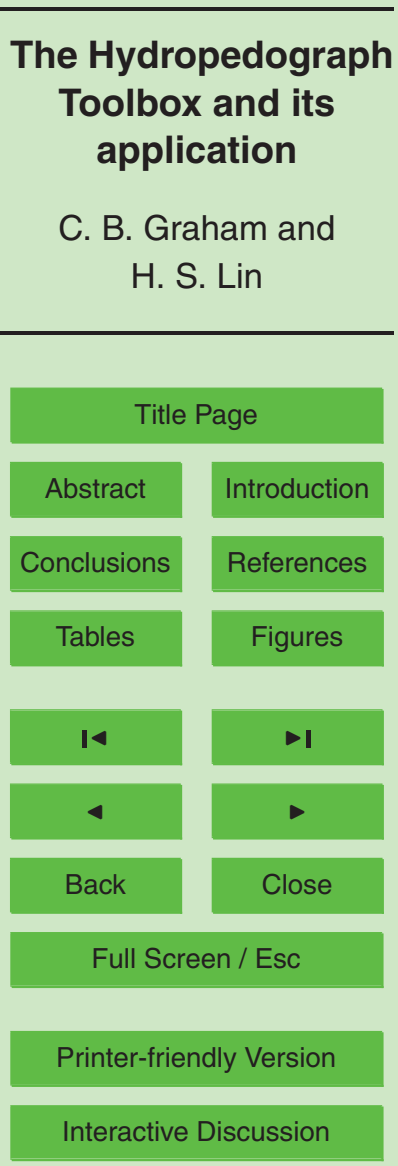




\subsection{Statistical summary}

Interpretation of soil moisture hydrological processes requires effective visualization of soil moisture time series data. The most common visualization of soil moisture time series is a line plot of soil moisture vs. time for the duration of monitoring. While this

5 plot is helpful in identifying precipitation events, relative wet and dry conditions, and magnitude of summer dry down or spring wet up, it is often difficult to see finer patterns. In this module, we plot figures that present soil moisture time series in a number of ways to help the interpretation of various finer patterns.

Figure 3 shows soil moisture both as a typical line time series, and as a response 10 surface, where the $x$-axis is time, the $y$ axis is depth, and the color axis is volumetric soil moisture content. This plot is helpful for identifying relatively dry and wet horizons within a soil profile and their time periods. Figure 4 further shows the cumulative frequency distribution of soil moisture at each of the monitored soil depths, where the $y$ axis is water content and the $\mathrm{x}$-axis is the fraction of the total data record where soil moisture 15 is above the stated water content. These plots are repeated with relative saturation instead of absolute soil water content to demonstrate patterns without effects from total porosity and residual water content. The third plot shows box and whisker plots for each horizon, showing the mean, median, $75 \%$ ranges, $95 \%$ ranges, and outliers of the soil moisture data record for each monitored depth. The fourth and fifth plots show time series of box and whisker plots, with the fourth showing soil moisture binned into a user inputted time step, and the fifth showing monthly values. The sixth plot is a histogram of soil moisture values, with a Gaussian curve fit to the histogram distribution (Fig. 4). The seventh is a plot of the soil moisture storage in the entire profile, with storage as the sum of the soil moisture measurements multiplied by the depth range each sensor represents. Optional Excel spreadsheets are generated with tables of all data in each of the above stated plots.

HESSD

9, 14231-14271, 2012

The Hydropedograph

Toolbox and its application

C. B. Graham and H. S. Lin

Title Page

Abstract Introduction

Conclusions

Tables

References

Figures

14

4

Back

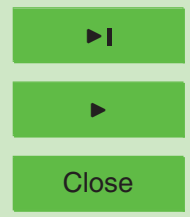

Full Screen / Esc

Printer-friendly Version

Interactive Discussion 


\subsection{Moisture release curve}

The soil moisture release curve (the relationship between soil moisture content and matric potential) is a dominant control on the flux and storage of water. A number of empirical equations have been developed to characterize this relationship, including the

5 Gardner (1958), Brooks and Corey (1964), and van Genuchten (1980) models, among others. These three common models all capture the apparent exponential relationship between soil moisture content and matric potential.

The Gardner (1958) model takes the form:

$\psi=a \theta^{-b}$,

10 where $\psi$ is the matric potential, $\theta$ is the volumetric water content, and $a$ and $b$ are fitting parameters.

The Brooks and Corey (1964) model takes the form:

$\psi=\alpha S^{1 / \lambda}$

where $\alpha$ and $\lambda$ are fitting parameters, and $S$ is the dimensionless water content defined 15 as:

$S=\frac{\theta-\theta_{\mathrm{r}}}{\theta_{\mathrm{s}}-\theta_{\mathrm{r}}}$

where $\theta$ is the volumetric soil moisture, $\theta_{\mathrm{r}}$ is the residual water content, and $\theta_{\mathrm{s}}$ is the saturated water content.

The van Genuchten (1980) model takes the form:

$20 \quad \psi=\frac{\left(S^{1 / m}-1\right)^{1 / n}}{\alpha}$,

where $S$ is the dimensionless water content as defined in Eq. (3), and $m, n$ and $\alpha$ are fitting parameters, with the generally accepted condition that $m=1-1 / n$.
HESSD

$9,14231-14271,2012$

The Hydropedograph

Toolbox and its application

C. B. Graham and

H. S. Lin

Title Page

Abstract

Introduction

Conclusions

References

Tables

Figures

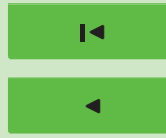

$\rightarrow$

Back

Close

Full Screen / Esc

Printer-friendly Version

Interactive Discussion 
In this module, time series of collocated matric potential probes are plotted against the soil moisture content data, and curves describing each of the above three models are fitted (Fig. 5). The model fits use a Monte Carlo methodology, with initial estimated ranges of parameter values entered by the user, along with the number of iterations 5 desired for the fitting. For half of the iteration number, random values of each parameter are inserted into the equations, and the Root Mean Squared Error (RMSE) of the predicted vs. measured soil moisture are minimized. The process is then repeated with a new range of parameters, this time $0-200 \%$ of the best-fit parameters from the first calibration. After the second calibration set, the parameter set with the minimum RMSE 10 is chosen as the best fit (Fig. 6).

Optional Excel data sheets are generated with the results of the model calibration, including RMSE and parameter values for each of the Monte Carlo parameter sets, with the best fit parameter set highlighted for each of the three models.

\subsection{Preferential flow}

15 Preferential flow, rapid subsurface flow that bypasses portions of the soil matrix, has been shown to be an important process in various soils, from humid to arid regions, and from agricultural to pasture and forested landscapes (Lin, 2010). Identification of the occurrence of preferential flow is a critical component to understanding field soil hydrological processes. Two operational definitions of preferential flow have appeared 20 in the hydrological and soil science literatures. In the first, preferential flow results in soil moisture response with depth faster than that predicted by the Darcy's law (Beven and Germann, 1982). In the second, preferential flow results in an out of sequence of soil moisture response to precipitation input within the same soil profile (Lin and Zhou, 2008), which can result from either vertical flow bypassing the footprint of a soil moisture sensor or from lateral flow from upslope area (Graham and Lin, 2011).

In this module, preferential flow is identified as instances where out of sequence of soil moisture sensor's response to precipitation events. If the user inputs a precipitation time series, rain events above a user input threshold are used to delineate precipitation

\section{HESSD}

$9,14231-14271,2012$

\section{The Hydropedograph \\ Toolbox and its application}

C. B. Graham and H. S. Lin

Title Page

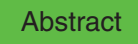

Introduction

Conclusions

Tables

References

Figures

14

$\rightarrow$

4

Back

Close

Full Screen / Esc

Printer-friendly Version

Interactive Discussion 
events. Here, soil moisture is examined immediately after the onset of each precipitation, and the sequence of soil moisture in various depths of a soil profile responding above a user input threshold is classified as either sequential or out of sequence response pattern. If there is no precipitation time series, the individual horizon's soil 5 moisture responses may be examined, and the first response of any horizon above a user input threshold is used to define the start of a precipitation event. Soil moisture response is then catalogued at each monitored soil depth or horizon, and the response order is then determined and the overall response pattern within a profile is classified accordingly following the procedures outlined in Graham and Lin (2011).

10 This module creates plots of the time series of soil moisture over grey bars indicating the type of flow regime (Fig. 7): (1) sequential flow (white) and (2) preferential flow - either out of sequence with all sensors respond to precipitation input (light grey) or a sensor at an intermediate depth has no response while bounding horizons respond (dark grey). From these figures one can see the frequency and timing of each type of 15 flow regime. Optional Excel data sheets are generated with horizon response time and magnitude for each identified precipitation event. The flow classification for each event is recorded.

\subsection{Diel signals in soil moisture}

Diel signals have often been observed in soil moisture, where soil moisture exhibits 20 a sinusoidal pattern with a daily wavelength, superimposed on seasonal trends. The two dominant sources of this signal are daily snowmelt during the winter and hydraulic redistribution during the summer.

In cold weather climates, daily impulses of snowmelt are a significant contribution to the soil water balance, with peak input in the late afternoon when incoming radiation 25 is the greatest. Thus snowmelt is generally characterized by peak soil moisture in the late afternoon, with a minimum in the early morning. The lag between peak snowmelt input and peak soil moisture is an indicator of soil moisture flux in these systems.

\section{HESSD}

$9,14231-14271,2012$

\section{The Hydropedograph \\ Toolbox and its application}

C. B. Graham and H. S. Lin

Title Page

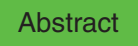

Introduction

Conclusions

Tables

References

Figures

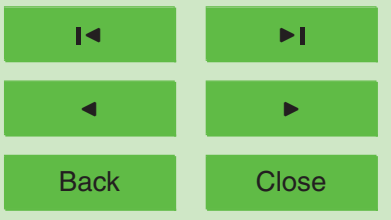

Full Screen / Esc

Printer-friendly Version

Interactive Discussion 
Hydraulic redistribution, the flux of water from wet to dry soil depths via roots, is thought to be an important mechanism for retaining soil moisture during periods of drought stress. Hydraulic redistribution is generally characterized by sinusoidal diel signals where soil moisture reaches a daily minimum sometime after peak evapotran5 spiration in late afternoon and a daily maximum in late evening or early morning prior to evapotranspiration initiation (Barnard et al., 2010; Brooks et al., 2002).

Another source of diel signals in soil moisture measurements could be artifacts of daily air temperature fluctuations and/or poor probe temperature compensations (Saito et al., 2009). This module can be run using soil temperature time series. The potential o effect of temperature fluctuations on soil moisture measurements can be determined using output from the module running with soil moisture and temperature relationship (discussed in Sect. 2.5).

In this module, diel signals are determined by comparing soil moisture with a driving function exhibiting a diel pattern, such as potential evaporation, sapflow, or snowmelt. 15 Additionally, the module is equipped with an option for using a sine wave as a proxy for these drivers. For each timestep of soil moisture time series, a shorter time series of the surrounding $72 \mathrm{~h}$ is extracted. This shorter time series is then plotted against a corresponding $72 \mathrm{~h}$ of the driving time series, and the correlation coefficient is determined. When this correlation coefficient is greater than a user selected tolerance, there is considered a strong diel signal in the soil moisture. This tolerance value is somewhat arbitrary, but our experience shows that a correlation coefficient greater than 0.7 results in a readily apparent diel signal in soil moisture. The time of day of maximum correlation, the value of the maximum correlation, and the amplitude of the daily signal are all recorded in optional Excel output. This numeric method has been successfully used to identify diel signals in stream discharge in connection to transpiration by Graham et al. (2012).

As in the preferential flow module, the diel signals module creates plots where the soil moisture time series is superimposed over grey bars indicating the presence or absence of diel signals in soil moisture, as determined by the correlation between the
HESSD

$9,14231-14271,2012$

\section{The Hydropedograph \\ Toolbox and its application}

C. B. Graham and H. S. Lin

Title Page

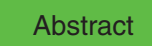

Introduction

Conclusions

Tables

References

Figures

14

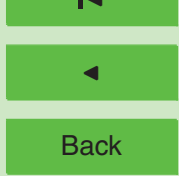

$\rightarrow$ I

$\checkmark$

Close

Full Screen / Esc

Printer-friendly Version

Interactive Discussion 
diel signal and soil moisture, and the user input tolerance level for a strong correlation (Fig. 8). In this case, the color of the bars indicates how many horizons exhibited diel flux on a given day, ranging from white (no horizon) to dark grey (all horizons) (Fig. 8). Optional Excel sheets are generated with the correlation coefficient between the diel 5 signal and soil moisture for each day, the amplitude of diel signal, and the time of maximum correlation for each day in the data record in each horizon.

\subsection{Soil moisture and temperature relationship}

Soil temperature is a key component of the energy and water balance, affecting ground heat flux, snow melt, hydraulic conductivity, and other landscape processes or soil properties. Understanding the relationship between soil temperature and soil moisture is also critical for understanding the pattern of subsoil bacterial growth, carbon flux, and soil weathering. Modeling soil temperature is also critical for determining periods of subsurface freezing and periods of high soil temperatures.

There are three components of the temperature module in the Hydropedograph Toolbox. First, soil temperature is plotted in the same way as the soil moisture, with a standard time series line plot, and a colorfield of temperature with depth (Fig. 9 upper panel). In the second set of plots, for each time step, the temperature is plotted against the soil moisture at the same depth (Fig. 9 lower panel). The measurement point density at each soil temperature and moisture combination (at $0.1^{\circ} \mathrm{C}$ and $0.1 \mathrm{~m}^{3} \mathrm{~m}^{3}$ reso-

20 lutions over the range of all measurements) is calculated, and expressed in the color field behind the individual temperature points. Due to the wide range of point densities, the natural log of density is expressed in the color field. The final component of the temperature module is a model of soil temperature pattern (Fig. 10a) of the form

$\mathrm{T}_{(t)}=\mathrm{MAT}+A \sin \left(\omega\left(t+t_{0}\right)\right)$,

25 where $\mathrm{T}_{(t)}$ is the temperature at time $t$, MAT is the mean annual temperature, $A$ is the amplitude of the annual temperature fluctuations, $\omega$ is the radial frequency $(2 \pi \times 1 \mathrm{yr})$, and $t_{0}$ is the time of maximum temperature. The current module does not include daily
HESSD

$9,14231-14271,2012$

The Hydropedograph

Toolbox and its application

C. B. Graham and H. S. Lin

Title Page

Abstract Introduction

Conclusions

Tables

References

Figures

14

$\rightarrow$

4

Back

Close

Full Screen / Esc

Printer-friendly Version

Interactive Discussion 
temperature fluctuations, but rather looks at seasonal trends. The temporal resolution of the calibration temperature time series does not impact the model fits.

The module is built to account for instances when a full year's data is not available, so MAT and A are not taken directly from the soil temperature time series, but are cali5 brated values (along with $t_{0}$ ). Using a Monte Carlo approach, MAT and A are randomly assigned to values $50-100 \%$ of observed values, and $t_{0}$ is assigned to \pm 75 days of the maximum measured temperature, and fit to Eq. (5). The RMSE is calculated, and the fit with the lowest RMSE is recorded (Fig. 10b). Generally, 1000 iterations of the Monte Carlo simulations were found to adequately explore the parameter space.

10 Products of the temperature modeling component of this module include plots of modeled and measured temperature at each soil horizon, including a subsample of "good" model fits and the best fit model, and dotty plots showing the results of the Monte Carlo calibration (Fig. 10). In these plots, the parameter values are plotted against the RMSE of the model. The shape of these dot fields indicates whether the parameters are well defined or not. Optional Excel data sheets are generated with the RMSE and parameter values for all parameter sets, with the best fit parameter set highlighted. The Excel data sheets also include some statistics of the measured temperature distribution in each soil horizon (i.e., mean, median, and range).

\section{Case study: Shale Hills Critical Zone Observatory (SHCZO)}

20 At the SHCZO, soil moisture content has been continuously monitored in real-time since 2005 at a number of sites (Fig. 1). While the soil moisture monitoring at the SHCZO encompasses all landscape positions, for simplicity purpose this case study will focus on three sites along a hillslope transect to demonstrate the utility of the Hydropedograph Toolbox. These three sites along a north-facing planar hillslope are heretofore referred to the ridge, the midslope, and the toeslope sites (Fig. 1).

Soil moisture and temperature have been measured with Decagon Devices' capacitance probes (moisture accuracy $\pm 3 \%$, precision $\pm 0.1 \%$; temperature accuracy $\pm 1{ }^{\circ} \mathrm{C}$,

\section{HESSD}

$9,14231-14271,2012$

The Hydropedograph

Toolbox and its application

C. B. Graham and H. S. Lin

Title Page

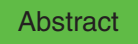

Introduction

Conclusions

Tables

References

Figures

14

- I

4

Back

Close

Full Screen / Esc

Printer-friendly Version

Interactive Discussion
$>$

Interactive Discussion 
precision $\pm 1^{\circ} \mathrm{C}$ ), while matric potential has been monitored with Campbell Scientific's 229 heat dissipation probes (accuracy and precision $\pm 1 \mathrm{kPa}$ ). Data were collected at $10 \mathrm{~min}$ intervals for the duration of the monitoring. For the simplicity of this case study, the 10 min data were interpolated into hourly averages using a linear interpolation func5 tion, and the data from 1 January 2011 through 31 December 2011 were used in this demonstration.

The ridge site is located at near the top of a north-facing hillslope (Fig. 1). The soil is classified as the Weikert soil series, a loamy-skeletal, mixed, active, mesic Lithic Dystrudept. This is the predominant soil type in the catchment, comprising $78 \%$ of the 10 area, and is characterized as a thin soil on hilltops or on planar or convex hillslopes, with depth to fractured shale bedrock $\leq 0.5 \mathrm{~m}$. Soil moisture and temperature sensors were installed at $10,20,30,40$, and $50 \mathrm{~cm}$ depths.

The midslope site lies approximately $30 \mathrm{~m}$ downslope of the ridge site along the steep north-facing planar hillslope. Here the soil remains Weikert, with a soil depth of $50 \mathrm{~cm}$. 15 The local slope is $30^{\circ}$. Soil moisture and temperature sensors were also installed at $10,20,30,40$, and $50 \mathrm{~cm}$ depths.

The toeslope site lies at the base of the hillslope, another $40 \mathrm{~m}$ directly downslope of the midslope site. Here the soil is classified as the Ernest soil series, a fine-loamy, mixed, superactive, mesic Aquic Fragiudult. These soils are the predominant soil in the valley of the catchment, and are characterized by deeper soils $(>3 \mathrm{~m})$ with some redoximorphic features (indicating periodic saturation). The monitoring site lies on a small bench $1 \mathrm{~m}$ upslope from the stream channel. Soil moisture and temperature sensors were installed at $10,20,30,40$, and $60 \mathrm{~cm}$ depths as comparable to the other two sites.

The ridge, midslope, and toeslope sites used in this case study currently do not have collocated matric potential data. To demonstrate the moisture release curve module of the toolbox, we analyzed soil moisture and collocated matric potential data from another site with the same soil type and vegetation as the ridge site, but with somewhat
HESSD

$9,14231-14271,2012$

\section{The Hydropedograph \\ Toolbox and its application}

C. B. Graham and H. S. Lin

Title Page

Abstract

Introduction

Conclusions

Tables

References

Figures

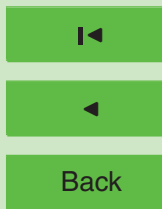

$\rightarrow$

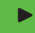

Close

Full Screen / Esc

Printer-friendly Version

Interactive Discussion 
shallower soil $(37 \mathrm{~cm})$. Soil moisture and matric potential probes at this site were collocated at $5,7,10,17$, and $37 \mathrm{~cm}$ depths.

The entire catchment is overlain by a litter layer, thus nearly all soils have an approximately $0.05 \mathrm{~m}$ thick organic layer (Oe horizon) comprised of decaying leaf litter and 5 other organic materials, which may become dry in the summer inducing hydrophobicity. Soils on the hillslopes generally have a silt loam texture with many shale fragments, a moderately developed soil structure, and high permeability, and thus generally well drained (Lin et al., 2006).

\subsection{Summary graphs}

10 The summary module makes a number of plots to demonstrate the basic characteristics of the measured soil moisture time series. Figure 3 shows the time series of soil moisture at the three sites. From these plots, we can easily see some similarities in the temporal patterns of soil moisture at the three sites, where the summer is relatively dry. Large differences are evident, however, in the response to fall precipitation and spring snowmelt events. At the ridge site, soil moisture at the deepest probe responds to water input with large increases in soil moisture when compared to the more muted response at the shallower horizons and at all horizons at the midslope location. At the toeslope site, large responses to precipitation are seen at most depths, with these large soil moisture responses indicating temporary saturation during precipitation events in the

fall and spring. Such large soil moisture responses were seen at the base of the profile at the ridge site, at no depth at the midslope site, but at most depths at the toeslope site.

The relative frequency of saturated and desiccated conditions are better quantified when looking at the relative saturation cumulative frequency plots, where the soil moisture ranges from 0 (residual water content) to 1 (field saturation), and are plotted against the cumulative frequency of occurrence (Fig. 4). These plots are characterized by three periods. At the lowest water content, moisture increases with increased cumulative frequency indicating evaporation driven dry-down in the summer. At the
HESSD

9, 14231-14271, 2012

\section{The Hydropedograph \\ Toolbox and its application}

C. B. Graham and H. S. Lin

Title Page

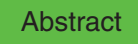

Introduction

Conclusions

Tables

References

Figures

14

4

Back

Full Screen / Esc

Printer-friendly Version

Interactive Discussion 
transect in the Shale Hills catchment, this period occupies $\sim 25 \%$ of the year at the ridge site, $\sim 18 \%$ at the midslope site, and $\sim 12 \%$ at the toeslope site. This indicates that moving from the toeslope towards the ridge, the effective length of the summer drought increases, and more time is spent below field capacity. At the toeslope site, 5 a significant portion of the year (up to $20 \%$ ) is at saturated conditions at 30 to $60 \mathrm{~cm}$ depths, as indicated by the secondary plateau at high water content in Fig. 4. The midslope and ridge sites are at maximum water content for a very short period, generally less than $1 \%$ of the year, indicating no periods of extended saturated condition (Fig. 4). The large difference between field capacity and maximum water content in the deepest 10 depth at the ridge site suggests the short periods of saturation observed in the time series plots. For much of the year ( $60-75 \%)$, water content at all sites stays at around field capacity, as seen in the long bench in the middle of each plot in Fig. 4, where soil moisture does not vary with increased probability. The tight bunching of the cumulative probability curves at the midslope suggests that the horizons are all rising and falling 15 in a similar manner, and that this site is dominated by relatively free drainage, with little drainage restriction at the base of the profile. The extended saturated conditions at the toeslope site, combined with the rapid transition from field capacity to saturated condition indicated not a gradual wetting-up, but a rapid filling from the bottom of the soil profile. This was due to incoming subsurface lateral flow from the surrounding hillslopes during large storm events, as supported by our early findings (Lin and Zhou, 2008).

\subsection{Moisture release curves}

The soil moisture release curve module can fit the models of van Genuchten, Brooks and Corey, and Gardner (Fig. 5). There was a close agreement between the van Genuchten and Brooks and Corey models, with nearly identical RMSE at each depth 25 (Table 1). The van Genuchten and Brooks and Corey model fits were all good despite the considerable amount of hysteresis observed in the moisture release curve, with RMSE under 1.63 for all depths. The Gardner model, while fitting 5 and $10 \mathrm{~cm}$ data

\section{HESSD}

$9,14231-14271,2012$

\section{The Hydropedograph \\ Toolbox and its application}

C. B. Graham and H. S. Lin

Title Page

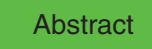

Introduction

Conclusions

Tables

References

Figures

14

4

Back

Close

Full Screen / Esc

Printer-friendly Version

Interactive Discussion 
well, had poor fits for other depths, where high RMSE coincided with large Gardner model parameter a (Table 1).

The Monte Carlo iterations of the model parameters were plotted against the model fit (RMSE) to assess model performance. In the case of a well-defined model, only 5 certain parameter values result in good model fit, indicating that the parameters have some physical basis and the model is not overly parameterized. A distinct shape in the dotty plots of model fit for different parameters (Fig. 6), with an isolated area where low RMSE models are possible, indicates model parameters are well defined and model equifinality is not a concern (Beven and Freer, 2001). Model parameters were well10 defined for the van Genuchten and Brooks and Corey models, as seen in Fig. 6. The $b$ parameter in the Gardner model was well defined, but the a parameter was not, perhaps explaining the difficulty in fitting the Gardner model to the data from certain depths.

\subsection{Preferential flow}

In this module, three parameters are required for determining the occurrence of preferential flow: the time between precipitation events, the minimum increase in soil moisture required for a significant response, and the minimum time required for a response to register in a soil moisture sensor. When running this module, these three parameters must be tuned to get a proper identification of all events and soil moisture responses. In the case study presented here, precipitation events were delineated as $24 \mathrm{~h}$ of no precipitation, and soil moisture response of $1 \%$ minimum change by volume was considered needed (see Graham and Lin, 2011 for more details). Shorter time between events resulted in short events with insufficient soil moisture recession, while longer time between events resulted in long events with multiple apparent events being 25 merged. Smaller than 1\% (by volume) soil moisture response resulted in false positives where diel fluctuations in soil moisture were classified as responses, while larger than $1 \%$ (by volume) soil moisture response resulted in obvious soil moisture responses not being picked up by the algorithm.
HESSD

$9,14231-14271,2012$

\section{The Hydropedograph \\ Toolbox and its application}

C. B. Graham and H. S. Lin

Title Page

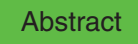

Introduction

Conclusions

Tables

Figures

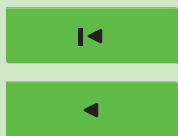

$\rightarrow$ I

Back

Close

Full Screen / Esc

Printer-friendly Version

Interactive Discussion 
A different number of precipitation events were recorded at each site, as soil moisture response data was used as an indicator of an event in this case study, rather than the precipitation record (due to uncertainties in the precipitation record at the sites and the fact that throughfall varied among the sites). From the ridge site to the midslope 5 and to the toeslope sites, the delineated event numbers were 48, 51, and 59, respectively. At some sites, for some events, the soil moisture rise from the precipitation input was not observed or not large enough to be recorded as a response, a phenomenon apparently more common on the ridge and midslope sites than the toeslope site. At all the three sites, preferential flow was frequent, occurring during $58 \%$ (ridge), $39 \%$ (mid- slope), and $53 \%$ (toeslope) of the identified soil moisture responses (Table 2). Preferential flow was concentrated during the summer at the midslope site, while preferential flow events were more evenly distributed over the year at the toeslope and ridge sites (Fig. 7). These findings corroborate the findings of Graham and Lin (2011) who used the similar definition of preferential flow at other soil profiles at the SHCZO and found 15 that preferential flow was common at all topographic positions due to a combination of lateral subsurface flow in the wet season and hydrophobicity in the dry season.

\subsection{Diel fluctuations}

The diel signal module identifies instances of diel fluctuations in soil moisture at various depths. Daily snow melt rates at the Shale Hills are infrequently of sufficient size to 20 induce winter diel signals, and the majority of diel signals observed at the Shale Hills occurred during the growing period, suggesting that the observed diel signals were an indication of vegetation activity, either hydraulic redistribution or daily patterns of water extraction by trees. A user input parameter determines the Pearson correlation $(r)$ needed by the module for the diel signal to be considered as significant. After some testing in the case study, an $r$ value of 0.7 agrees with visual identification of diel signals. Greater $r$ values resulted in removal of clearly sinusoidal behavior, while smaller values included precipitation events with vaguely sinusoidal shapes.

\section{HESSD}

9, 14231-14271, 2012

\section{The Hydropedograph \\ Toolbox and its application}

C. B. Graham and H. S. Lin

Title Page

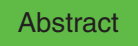

Introduction

Conclusions

Tables

References

Figures

14

4

Back

Full Screen / Esc

Printer-friendly Version

Interactive Discussion 
Another possible source of diel signals observed in soil moisture time series could be artifacts due to insufficient temperature correction in sensor calibration, as many soil moisture sensors have been shown to be affected by temperature (Kizito et al., 2008). In the case of the Shale Hills, the diel signals in soil moisture extend to various 5 depths, where soil temperature fluctuations are small (see Figs. 8 and 9). During periods of strong diel signal, minimum soil moisture was occurring in the early afternoon (14:00-16:00), with minimum soil moisture in the morning (3:00-6:00). Soil temperature during this period peaked in the evening (19:00-20:00), suggesting the observed patterns in soil moisture are not an artifact from temperature impact on the sensor.

10 The diel signals are most pronounced at the midslope site, where they were observed 146 times between the five sensors installed at various depths, with greatest frequency in the 20,30 , and $40 \mathrm{~cm}$ depths (Table 3 ). Diel signals were observed at one or more horizons 53 days between 27 March and 12 September (Fig. 8). The toeslope site had the least frequent diel signals, with the majority of signal observed in the upper 15 two depths. There were 58 observed diel signals spread between the five sensors installed at the toeslope site, and 40 days of diel signals with at least one sensor between 30 May and 9 October (Table 3). The ridge site appeared to be an intermediate of the other two sites, with 115 observed diel signals, biased towards the lower three depths. The ridge site had the most days with observed diel signal (55), beginning 26 March and running through 12 September. The observed signals in March at the ridge and midslope sites were isolated from the summer group of diel signals, indicating a possible snowmelt source of the signal. Beyond those observations, the diel signals began on 7 May for the ridge site and on 30 May for the midslope and toeslope sites (Fig. 8).

\subsection{Soil moisture and temperature relationship}

25 The temperature module plots soil temperature as time series and against soil moisture, and fits a seasonal model to soil temperature data. Plots of the three soil profiles show soil temperature following typical patterns, with surface horizons (10 and $20 \mathrm{~cm}$ ) exhibiting daily temperature fluctuations superimposed on an annual pattern of

\section{HESSD}

$9,14231-14271,2012$

\section{The Hydropedograph \\ Toolbox and its application}

C. B. Graham and H. S. Lin

Title Page

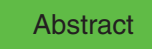

Introduction

Conclusions

Tables

References

Figures

14

$\rightarrow$

4

Back

Close

Full Screen / Esc

Printer-friendly Version

Interactive Discussion 
increased summer temperature (Fig. 9). Deeper horizons showed a lagged response to the seasonal signal, and greatly damped daily fluctuation. From the beginning of the time series until March, soil temperature was relatively constant in all the horizons at all the sites. The lack of daily fluctuations indicates the soil was snow covered, since 5 temperatures at the base of a snow pack are generally consistently near $0{ }^{\circ} \mathrm{C}$. At the midslope location the apparent snow cover lasted the longest, 15 days longer than the toeslope site and 10 days longer than at the ridge site in 2011.

When plotted against soil moisture, the three profiles all exhibited an L-shaped pattern (Fig. 9) where water content was fairly constant over a wide range of soil temperatures $\left(\sim 0\right.$ to $\left.15^{\circ} \mathrm{C}\right)$, after which soil water content dropped while temperature remained fairly constant. This is consistent with the observation above that water content at the Shale Hills remains at or above field capacity for much of the year, dropping below only during the growing season, when vegetation turns on and soil temperatures rise.

An additional function of this module is to produce a model of soil temperature at 15 each horizon using Eq. (5) (Fig. 10). Model fits were satisfactory, considering the dayto-day variability, with RMSE decreasing with depth (average RMSE was 1.48 at $10 \mathrm{~cm}$ and 1.03 at the deepest) as the daily fluctuations were damped by the overlying soil (Table 4). The key parameters in the soil temperature model behaved as expected in the model fits, with the mean annual temperature fairly stable (standard deviation of $\sim 0.2^{\circ} \mathrm{C}$ for the three profiles), the annual amplitude decreasing with depth, and the lag (time of peak modeled soil temperature) increasing through the year with depth (Table 4). At all depths, the midslope profile had the lowest mean annual temperature and highest annual amplitude. This resulted from the midslope site having the lowest modeled winter temperatures, while the highest modeled summer temperatures were similar for the three sites, perhaps due to lower snowpack insulation due to the steep slopes.

\section{HESSD}

$9,14231-14271,2012$

\section{The Hydropedograph \\ Toolbox and its application}

C. B. Graham and H. S. Lin

Title Page

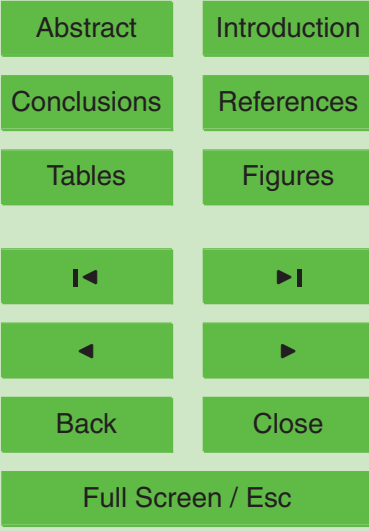

Printer-friendly Version

Interactive Discussion 


\section{Discussion}

The Hydropedograph Toolbox has allowed for a rapid and systematic assessment of soil moisture, temperature, and matric potential patterns at different depths in three soil profiles along a topographic gradient in the Shale Hills Catchment. While additional

5 time is needed for more thorough analysis, creating all plots and affiliated Excel data files through the toolbox, as presented in this case study, took less than 10 min per soil profile. Preprocessing of data, including putting timestamp in decimal format and data in adjoining columns, took less than 5 min per time series. From our experience in earlier work prior to the development of this toolbox, it would have taken hours, if not days, for each module if performed from scratch. We feel that the analyses enabled by this Hydropedograph Toolbox cover a wide range of soil hydrological processes (preferential flow and hydraulic redistribution) and properties (moisture, temperature, and matric potential). Future versions of this toolbox can be further enhanced and expanded.

\subsection{Scientific understanding of individual sites gained through the use of the toolbox}

The toeslope site exhibited periodic saturation from the base of the profile up to near the soil surface, as illustrated by both the time series plots and the cumulative frequency distribution plots (Figs. 3 and 4). These saturation events often lasted multiple days, indicating perched water table. The toeslope site exhibited the shortest summer drydown, with less than $15 \%$ of the year below field capacity (compared to $20 \%$ and $25 \%$ at the midslope and ridge sites, respectively). As an apparent consequence of the reduced period of summer dry-down, the toeslope site had the most infrequent diel signals, generally occurring in the upper $20 \mathrm{~cm}$, implying less hydraulic redistribution is required to maintain sufficient water for the riparian vegetation. As a consequence of frequent saturation, the toeslope site also exhibited frequent preferential flow during large storm events because of subsurface lateral flow from the surrounding hillslopes.

The Hydropedograph

Toolbox and its application

C. B. Graham and H. S. Lin

Title Page

Abstract

Conclusions

Tables

14

4

Back

Full Screen / Esc

Printer-friendly Version

Interactive Discussion
-I

Close 
The time series and cumulative distribution plots (Figs. 3 and 4) show that the midslope site acted as an intermediary of the toeslope and ridge sites with respect to summer dry-down duration, despite exhibiting the longest snow covered period in the winter/spring transition. Unlike the toeslope or ridge sites, no saturation was observed 5 at any depths at the midslope site. However, diel signals were the most frequent at this site, occurring throughout the summer, often at all horizons and distributed more evenly with depth. This suggests hydraulic redistribution and water extraction occurred throughout this well-drained soil profile. Preferential flow was more concentrated during the summer at the midslope site. Analysis from the temperature module indicates 10 that the midslope site exhibits the greatest annual variation in temperature, as well as overall colder conditions.

At the ridge location, the time series plots showed episodic saturation at the deepest horizon (Fig. 3). Unlike the toeslope site, where saturation continued for days after an event, the saturation events at the ridge site were rapid, suggesting a temporary infiltration excess into the underlying bedrock (Lin and Zhou, 2008). Summer dry-down was the longest at this site, lasting over $25 \%$ of the annual time series. This extended dry-down corresponds to frequent diel signals in the summer months, generally concentrated more in the lower portion of this shallow soil profile. The preferential flow module identified frequent preferential flow at this ridge site during both dry and wet seasons, which were contributed to hydrophobicity associated with dry organic-rich surface soil in the summer and macropore flow associated with root channels and underlying fractured rock during the wet season.

\subsection{A holistic understanding of topographic effects on soil moisture at the Shale Hills}

25 The Hydropedograph Toolbox demonstrated the influence of topographic position on soil moisture evolution through one calendar year. Based on this case study, some conclusions can be made on the impact of topographic position on soil moisture dynamics. There were two main topographic differences between the three sites that

\section{HESSD}

9, 14231-14271, 2012

\section{The Hydropedograph \\ Toolbox and its application}

C. B. Graham and H. S. Lin

Title Page

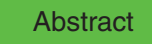

Introduction

Conclusions

Tables

References

Figures

14

4

Back

Full Screen / Esc

Printer-friendly Version

Interactive Discussion 
corresponded to the components of the topographic wetness index - upslope contributing area and slope - which have been used to predict soil moisture patterns in the hydrologic literature. The ridge and toeslope sites were both located at where the local slope was near zero, while the midslope site was midway down the steep $\left(30^{\circ}\right)$ 5 hillslope. The ridge site differed from the toeslope site in that there was essentially no upslope contributing area, while the toeslope had $70 \mathrm{~m}$ of hillslope draining into, with the midslope site as an intermediary.

The ridge and toeslope sites exhibited saturation at the lowest horizon (ridge) or throughout much of the soil profile (toeslope). The midslope site exhibited no satura10 tion events, and the parallel lines in the cumulative distribution plots suggest that this midslope site is characterized by free drainage throughout the year. These findings suggest more efficient drainage at the midslope site, where water can move vertically into the fractured bedrock or laterally downslope. The saturation events at the toeslope were due to a perched water table emanating from the nearby stream channel and sub15 surface lateral flow from the surrounding hillslopes, while the flashy saturation at the ridge site was due to the reduced permeability of the underlying but fractured bedrock (Lin and Zhou, 2008).

The upslope contributing area seems to express itself in the relative wetness of the toeslope site and the relative dryness of the ridge and midslope sites. The cumulative frequency distributions of the soil moisture show that summer dry-down duration increased from the toeslope to the ridge. Summer diel signals were most common at the ridge and midslope sites. Interestingly, the winter snowpack duration, as indicated by steady winter soil temperatures near $0^{\circ} \mathrm{C}$, were correlated with neither diel signal frequency nor summer dry-down duration, indicating that the effect of snowpack on summer soil moisture is minimal at the Shale Hills. Additionally, preferential flow was more concentrated during the summer at the midslope site, but was more widespread over both dry and wet seasons in the ridge and toeslope sites.
HESSD

$9,14231-14271,2012$

\section{The Hydropedograph \\ Toolbox and its application}

C. B. Graham and H. S. Lin

Title Page

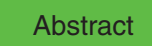

Introduction

Conclusions

Tables

References

Figures

14

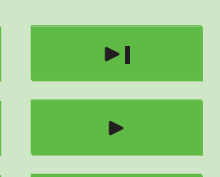

Back

Close

Full Screen / Esc

Printer-friendly Version

Interactive Discussion 


\subsection{Strengths and potentials of the Hydropedograph Toolbox}

The Hydropedograph Toolbox allows for a rapid, systematic, and consistent assessment of soil moisture time series, and is effective in identifying various trends within a soil profile and between sites. In the case study reported here, the toolbox is effective 5 in quickly generating graphical visualizations needed to analyze soil moisture temporal patterns at different topographic positions at the Shale Hills. The frequencies of preferential flow and diel signals have provided insights into subsurface flow dynamics and vegetation water use pattern, respectively, which are not intuitive and straight-forward to pick out from looking at the soil moisture time series data themselves. The toolbox 10 provides a quantitative framework to quickly determine the timing, magnitude, and frequency of various soil moisture responses to precipitation events, including saturation events, dry-down periods, preferential flow occurrence, and diel signal frequency.

We envision the Hydropedograph Toolbox as a first-cut for systematic and consistent soil moisture analysis, to be used for quickly identifying various possible patterns and interesting features or sites for further analysis. The toolbox can be further enhanced and expanded in future versions, especially after obtaining feedbacks from the scientific community via applications in different landscapes. The current version of the Hydropedograph Toolbox may also be used to generate hypothesis based on soil moisture monitoring data and their interpretations. For instance, the diel signal module showed that diel signals were observed at different soil depths at different sites, with signals confined to the upper $20 \mathrm{~cm}$ at the toeslope site and throughout the profile at the other upper slope sites. Several hypotheses may be generated from this observation, such as: (1) More vegetation water use and/or hydraulic redistribution at the ridge and midslope sites than that at the toeslope site; (2) Increased wetness at the 25 toeslope led to less hydraulic redistribution needed for vegetation growth; and (3) Different vegetation at the toeslope uses water from a different source area or depth as the valley at the Shale Hills tends towards conifers while the hillslopes are forested
HESSD

$9,14231-14271,2012$

The Hydropedograph

Toolbox and its application

C. B. Graham and H. S. Lin

Title Page

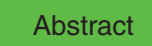

Introduction

Conclusions

Tables

References

Figures

14

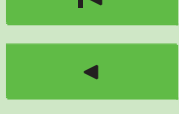

$\rightarrow 1$

Back

Close

Printer-friendly Version

Interactive Discussion 
with hardwoods. From such an analysis, further testing and data collections may be developed accordingly.

\section{Conclusions}

The Hydropedograph Toolbox has been built with an eye towards incorporating many 5 of the common analytical tools to comprehensively understand soil hydrological processes using multi-depth soil moisture time series datasets. To this end we have developed several modules that explore key hydrological processes including preferential flow, hydraulic redistribution (via the diel signals module), the relationship between soil moisture and matric potential or soil temperature, and the storage and fluxes of water in the soil profile. The list of analyses is by no means exhaustive with the current version of the program. However, we envision the Hydropedograph Toolbox as an open source community resource where additional analyses can be added and enhanced later. We have demonstrated in this paper the utility of this toolbox with a case study from a topographic transect of soil moisture profiles at the Shale Hills Critical Zone Observatory. We have illustrated the occurrence of preferential flow, diel fluxes of water, and seasonal storage dynamics in the hillslope, suggesting possible slope and upslope contributing area impacts on soil water storage, preferential flow, and hydraulic redistribution. It is expected that such a toolbox, with its continued enhancements and wide applications in various watersheds, can facilitate the study of comparative hydrology

Acknowledgements. This research was supported by the US National Science Foundation through the Shale Hills Critical Zone Observatory grant (EAR-0725019). Installations of soil moisture sensors and related data collections were assisted by the Penn State Hydropedology team members.

\section{HESSD}

9, 14231-14271, 2012

The Hydropedograph

Toolbox and its application

C. B. Graham and H. S. Lin

Title Page

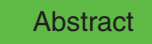

Introduction

Conclusions

References

Tables

Figures

14

4

Back

Close

Full Screen / Esc

Printer-friendly Version

Interactive Discussion 


\section{References}

Bales, R. C. Hopmans, J. W., O'Geen, A. T., Meadows, M., Hartsough, P. C., Kirchner, P., Hunsaker, C. T., and Beaudette, D.: Soil Moisture Response to Snowmelt and Rainfall in a Sierra Nevada Mixed-Conifer Forest, Vadose Zone J., 10, 786-799, 2011.

5 Barnard, H., Graham, C. B., Van Verseveld, V. J., Brooks J. R., Bond, B. J., and McDonnell J. J.: Mechanistic assessment of hillslope transpiration controls of diel subsurface flow: a steady-state irrigation approach, Ecohydrology, 3, 133-142, 2010.

Beven, K. and Freer, J.: Equifinality, data assimilation, and uncertainty estimation in mechanistic modelling of complex environmental systems using the GLUE methodology, J. Hydrol., 249,

10 11-29, 2001.

Beven, K. and Germann, P.: Macropores and water flow in soils, Water Resour. Res., 18, 13111325, 1982.

Beven, K. J. and Kirkby, M. J.: A physically based, variable contributing area model of basin hydrology, Hydrolog. Sci. Bull., 24, 43-69, 1979.

15 Bogena, H. R., Herbst, M., Huisman, J. A., Rosenbaum, U., Weuthen, A., and Vereecken, H.: Potential of Wireless Sensor Networks for Measuring Soil Water Content Variability, Vadose Zone J., 9, 1002-1013, doi:10.2136/vzj2009.0173, 2010.

Bond, B. J., Jones, J. A., Moore, G., Phillips, N., Post, D., and McDonnell, J. J.: The zone of vegetation influence on baseflow revealed by diel patterns of streamflow and vegetation

20 water use in a headwater basin, Hydrol. Process., 16, 1671-1677, 2002.

Brooks, R. H. and Corey, A. T.: Hydraulic properties of porous media, Colorado State University, Fort Collins, CO, 1964.

Brooks, J., Meinzer, F., Coulombe, R., and Gregg, J.: Hydraulic redistribution of soil water during summer drought in two contrasting Pacific Northwest coniferous forests, Tree Physiol., 22,

25 1107-1117, 2002.

Dingman, S. L.: Physical Hydrology, Prentice Hall, Upper Saddle River, New Jersey, 2002.

Dorigo, W. A., Wagner, W., Hohensinn, R., Hahn, S., Paulik, C., Xaver, A., Gruber, A., Drusch, M., Mecklenburg, S., van Oevelen, P., Robock, A., and Jackson, T.: The International Soil Moisture Network: a data hosting facility for global in situ soil moisture measurements, Hydrol. Earth Syst. Sci., 15, 1675-1698, doi:10.5194/hess-15-1675-2011, 2011.

Gardner, W. R.: Some steady state solutions of unsaturated moisture flow equations with applications to evaporation from a water table, Soil Sci., 85, 228-232, 1958.

\section{HESSD}

$9,14231-14271,2012$

The Hydropedograph

Toolbox and its application

C. B. Graham and H. S. Lin

Title Page

Abstract

Introduction

Conclusions

References

Tables

Figures

14

4

Back

Close

Full Screen / Esc

Printer-friendly Version

Interactive Discussion 
Graham, C. and Lin, H.: Controls and Frequency of Preferential Flow Occurrence: A 175-Event Analysis, Vadose Zone J., 10, 816-831, 2011.

Graham, C. B., Barnard, H. R., Kavanagh, K. L., and McNamara, J. P.: Catchment scale controls temporal connection of transpiration and diel fluctuations in streamflow, Hydrol. Process., 26, doi:10.1002/hyp.9334, 2012.

Hewlett, J. D. and Hibbert, A. R.: Factors affecting the response of small watersheds to precipitation in humid areas, in: Forest Hydrology, edited by: Sopper, W. E. and Lull, H. W., Pergamon Press, New York, 275-290, 1967.

Kizito, F., Campbell, C. S., Campbell, G. S., Cobos, D. R., Teare, B. L., Carter, B., and Hopmans, J. W.: Frequency, electrical conductivity and temperature analysis of a low-cost capacitance soil moisture sensor, J. Hydrol., 352, 367-378, 2008.

Lin, H. S.: Linking principles of soil formation and flow regimes, J. Hydrol., 393, 3-19, 2010.

Lin, $\mathrm{H}$. and Zhou, X.: Evidence of subsurface preferential flow using soil hydrologic monitoring in the Shale Hills catchment, Eur. J. Soil Sci., 59, 34-49, 2008.

Lin, H. S., Kogelmann, W., Walker, C., and Bruns, M.A.: Soil moisture patterns in a forested catchment: A hydropedological perspective, Geoderma, 131, 345-368, 2006.

Lundquist, J. and Cayan, D.: Seasonal and spatial patterns in diurnal cycles in streamflow in the western United States, J. Hydrometeorol., 3, 591-603, 2002.

Saito, T., Fujimaki, H., Yasuda, H., and Inoue, M.: Empirical Temperature Calibration of Capacitance Probes to Measure Soil Water, Soil Sci. Soc. Am. J., 73, 1931-1937, 2009.

Sklash, M. G. and Farvolden, R. N.: Role of groundwater in storm runoff, J. Hydrol., 43, 45-65, 1979.

Swarowsky, A, Dahlgren, R. A., Tate, K. W., Hopmans, J. W., and O'Geen, A. T.: Catchmentscale soil water dynamics in a Medierranenean-type Oak woodland, Vadose Zone J., 10, 800-815, 2011.

Takagi, K. and Lin, H. S.: Changing controls of soil moisture spatial organization in the Shale Hills Catchment, Geoderma, 193, 289-302, 2012.

Troxell, H.: The diurnal fluctuation in the ground-water and flow of the Santa Ana River and its meaning, T. Am. Geophys. Un., 17, 496-504, 1936.

30 Uchida, T., Kosugi, K. I., and Mizuyama, T.: Effects of pipeflow on hydrological process and its relation to landslide: a review of pipeflow studies in forested headwater catchments, Hydrol. Process., 15, 2151-2174, 2001.

\section{HESSD}

9, 14231-14271, 2012

The Hydropedograph

Toolbox and its application

C. B. Graham and H. S. Lin

Title Page

Abstract

Introduction

Conclusions

References

Tables

Figures

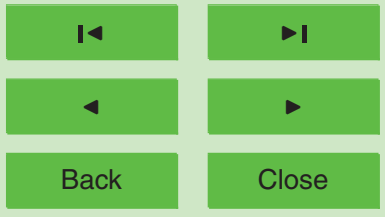

Full Screen / Esc

Printer-friendly Version

Interactive Discussion 
Uchida, T., Asano, Y., Mizuyama, T., and McDonnell, J.: Role of upslope soil pore pressure on lateral subsurface storm flow dynamics, Water Resour. Res., 40, 12401, doi:10.1029/2003WR002139, 2004.

van Genuchten, M. T.: A closed-form equation for predicting the hydraulic conductivity of unsaturated soils, Soil Sci. Soc. Am. J., 44, 892-898, 1980.

Vitvar, T., Burns, D., Lawrence, G., McDonnell, J., and Wolock, D.: Estimation of baseflow residence times in watersheds from the runoff hydrograph recession: method and application in the Neversink watershed, Catskill Mountains, New York, Hydrol. Process., 16, 1871-1877, 2002.

10 Western, A. W., Grayson, R. B., Blöschl, G., Willgoose, G. R., and McMahon, T. A.: Observed spatial organization of soil moisture and its relation to terrain indices, Water Resour. Res., 35, 797-810, 1999a.

Western, A. W., Grayson, R. B., and Green, T. R.: The Tarrawarra project: high resolution spatial measurement, modelling and analysis of soil moisture and hydrological response, Hydrol. Process., 13, 633-652, 1999b.

Zhu, Q. and Lin, H. S.: Impacts of soil properties, terrain attributes, and crop growth on soil moisture in an agricultural landscape, Geoderma 163, 45-54, 2011.

\section{HESSD}

9, 14231-14271, 2012

The Hydropedograph

Toolbox and its application

C. B. Graham and

H. S. Lin

Title Page

Abstract

Introduction

Conclusions

References

Tables

Figures

14

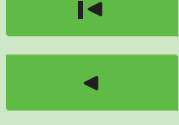

Back

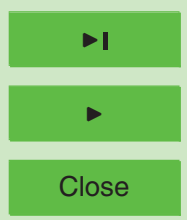

Full Screen / Esc

Printer-friendly Version

Interactive Discussion 


\section{HESSD}

\section{9, 14231-14271, 2012}

The Hydropedograph

Toolbox and its application

Table 1. The best-fit root mean squared error (RMSE) and the resulting parameters of van Genuchten, Brooks and Corey, and Gardner soil moisture release models outputted from the Hydropedograph Toolbox.

\begin{tabular}{cccccccccccccc}
\hline \multirow{2}{*}{ soil depths } & \multicolumn{2}{c}{ Volumetric soil moisture (\%) } & \multicolumn{2}{c}{ van Genuchten } & \multicolumn{3}{c}{ Brooks and Corey } & \multicolumn{2}{c}{ Gardner } \\
\hline$(\mathrm{cm})$ & Residual & Saturation & RMSE & alpha & $n$ & RMSE & $a$ & $b$ & RMSE & $a$ & $b$ \\
\hline 5 & 0.75 & 19.61 & 1.63 & 0.039 & 1.67 & 1.62 & 17.70 & 0.59 & 1.62 & 4795 & 1.89 \\
7 & 5.71 & 18.46 & 1.40 & 0.020 & 1.91 & 1.41 & 26.17 & 0.64 & 1.56 & 45982 & 2.55 \\
10 & 1.30 & 16.63 & 1.04 & 0.065 & 1.74 & 1.04 & 12.39 & 0.69 & 1.03 & 2355 & 1.93 \\
17 & 7.68 & 21.67 & 1.22 & 0.046 & 1.74 & 1.22 & 15.12 & 0.63 & 1.89 & 60112 & 2.67 \\
37 & 13.64 & 28.64 & 1.33 & 0.046 & 1.89 & 1.32 & 17.47 & 0.82 & 2.91 & 133034 & 2.61 \\
\hline
\end{tabular}

C. B. Graham and

H. S. Lin

Title Page

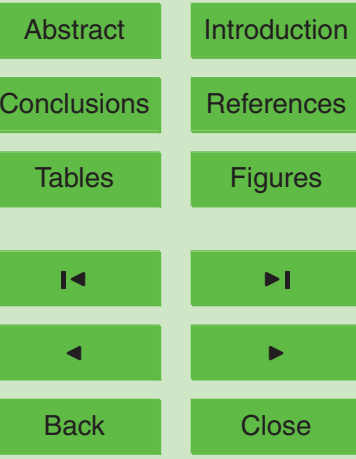

Full Screen / Esc

Printer-friendly Version

Interactive Discussion 


\section{HESSD}

\section{$9,14231-14271,2012$}

The Hydropedograph

Toolbox and its application

Table 2. Summary of flow regimes (number of events and \% of total events) at the Shale Hills for 2011 along the hillslope transect. Sequential flow is characterized by all horizons responding to precipitation input in sequential order with depth. Two scenarios of preferential flow are identified: (1) out of sequence indicates one or more horizons responding out of order with respect to depth and (2) missing horizon indicates that one or more horizon did not respond while bounding horizons did.

\begin{tabular}{|c|c|c|c|c|c|c|c|}
\hline \multirow{2}{*}{$\begin{array}{c}\text { Hillslope } \\
\text { site }\end{array}$} & \multirow{2}{*}{$\begin{array}{c}\text { Number of } \\
\text { precipitation events } \\
48\end{array}$} & \multicolumn{2}{|c|}{ Sequential flow } & \multicolumn{2}{|c|}{$\begin{array}{l}\text { Preferential flow } \\
\text { (out of sequence) }\end{array}$} & \multicolumn{2}{|c|}{$\begin{array}{l}\text { Preferential flow } \\
\text { (missing horizon) }\end{array}$} \\
\hline & & 20 & $42 \%$ & 20 & $42 \%$ & 8 & $17 \%$ \\
\hline Midslope & 51 & 31 & $61 \%$ & 10 & $20 \%$ & 10 & $20 \%$ \\
\hline Toeslope & 59 & 28 & $47 \%$ & 14 & $24 \%$ & 17 & $29 \%$ \\
\hline
\end{tabular}

C. B. Graham and H. S. Lin

Title Page

Abstract Introduction

Conclusions References

Tables Figures

14

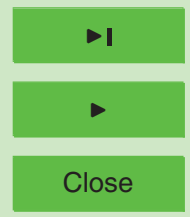

Back

Full Screen / Esc

Printer-friendly Version

Interactive Discussion 


\section{HESSD}

\section{$9,14231-14271,2012$}

The Hydropedograph

Toolbox and its application

C. B. Graham and

H. S. Lin

Table 3. Number of days with diel signals at each soil depth in 2011 and number of days with 0 to 5 soil horizons exhibiting diel signals at the three sites along the hillslope transect.

\begin{tabular}{|c|c|c|c|c|c|c|c|c|c|c|c|}
\hline \multirow{2}{*}{$\begin{array}{l}\text { Hillslope } \\
\text { position }\end{array}$} & \multicolumn{5}{|c|}{$\begin{array}{l}\text { Diel signal at each soil depth } \\
\qquad(\mathrm{cm})\end{array}$} & \multicolumn{6}{|c|}{$\begin{array}{l}\text { Number of soil horizons with diel } \\
\text { fluctuation }\end{array}$} \\
\hline & 10 & 20 & 30 & 40 & $50 / 60$ & 0 & 1 & 2 & 3 & 4 & 5 \\
\hline & 20 & 9 & $\checkmark$ & 27 & 24 & & 1 & 21 & 0 & 9 & \\
\hline Midslope & 12 & 36 & 32 & 38 & 28 & 312 & 13 & 11 & 12 & 10 & 7 \\
\hline Toeslope & 17 & 34 & 0 & 3 & 4 & 325 & 23 & 16 & 1 & 0 & 0 \\
\hline
\end{tabular}

Title Page

Abstract Introduction

Conclusions References

Tables Figures

14

4

Back

Close

Full Screen / Esc

Printer-friendly Version

Interactive Discussion 


\section{HESSD}

\section{9, 14231-14271, 2012}

The Hydropedograph Toolbox and its application

the three hillslope positions (the ridge, the midslope, and the toeslope).

\begin{tabular}{|c|c|c|c|c|c|}
\hline \multicolumn{6}{|c|}{ Ridge } \\
\hline Soil depth & $10 \mathrm{~cm}$ & $20 \mathrm{~cm}$ & $30 \mathrm{~cm}$ & $40 \mathrm{~cm}$ & $50 \mathrm{~cm}$ \\
\hline Mean Annual Temp & 10.43 & 10.80 & 11.06 & 10.99 & 10.67 \\
\hline Amplitude & 8.98 & 8.56 & 8.40 & 8.13 & 7.73 \\
\hline Time of max. temp. & 1 Aug 11 14:00 & 1 Aug 11 7:45 & 31 Jul 11 1:59 & 6 Aug 11 20:24 & 6 Aug $1114: 09$ \\
\hline Model RMSE & 1.42 & 1.28 & 1.11 & 1.08 & 0.90 \\
\hline \multicolumn{6}{|c|}{ Midslope } \\
\hline Soil depth & $10 \mathrm{~cm}$ & $20 \mathrm{~cm}$ & $30 \mathrm{~cm}$ & $40 \mathrm{~cm}$ & $50 \mathrm{~cm}$ \\
\hline Mean Annual Temp & 10.30 & 9.95 & 10.17 & 9.93 & 9.95 \\
\hline Amplitude & 10.04 & 9.35 & 9.28 & 8.72 & 8.43 \\
\hline Time of max. temp. & 28 Jul 11 19:56 & 31 Jul $118: 48$ & 1 Aug 11 20:23 & 3 Aug 11 17:50 & 8 Aug 11 11:53 \\
\hline Model RMSE & 1.58 & 1.29 & 1.26 & 1.07 & 1.02 \\
\hline \multicolumn{6}{|c|}{ Toeslope } \\
\hline Soil depth & $10 \mathrm{~cm}$ & $20 \mathrm{~cm}$ & $30 \mathrm{~cm}$ & $40 \mathrm{~cm}$ & $60 \mathrm{~cm}$ \\
\hline Mean Annual Temp & 10.59 & 10.54 & 10.58 & 10.08 & 10.69 \\
\hline Amplitude & 8.84 & 6.75 & 7.76 & 7.79 & 8.57 \\
\hline Time of max. temp. & 1 Aug 11 19:21 & 8 Aug 11 11:03 & 5 Aug $115: 37$ & 4 Aug $119: 18$ & 1 Aug $114: 47$ \\
\hline Model RMSE & 1.43 & 0.95 & 1.17 & 1.07 & 1.18 \\
\hline
\end{tabular}

C. B. Graham and

H. S. Lin

Title Page

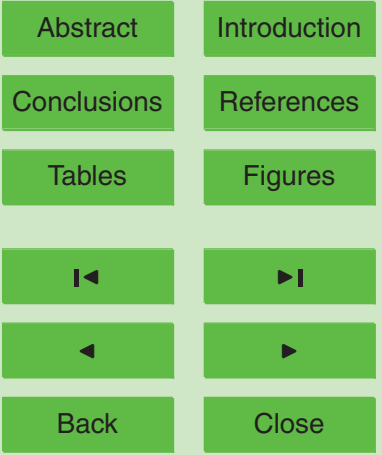

Full Screen / Esc

Printer-friendly Version

Interactive Discussion 


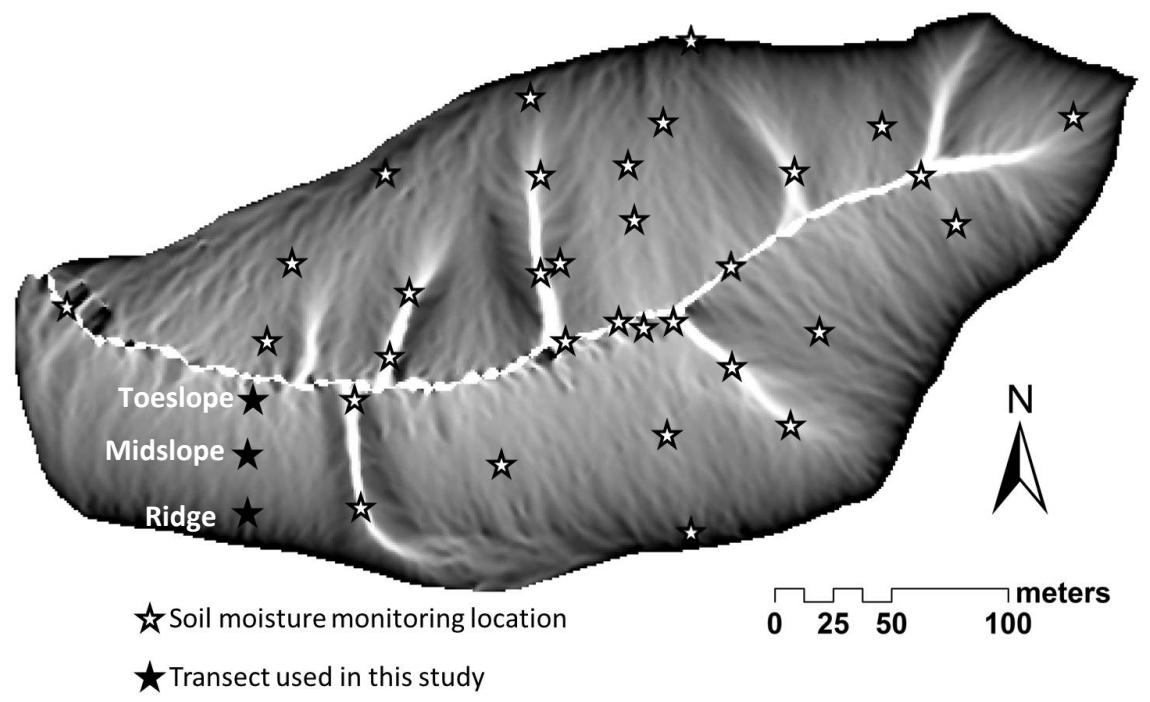

HESSD

$9,14231-14271,2012$

The Hydropedograph Toolbox and its application

C. B. Graham and H. S. Lin

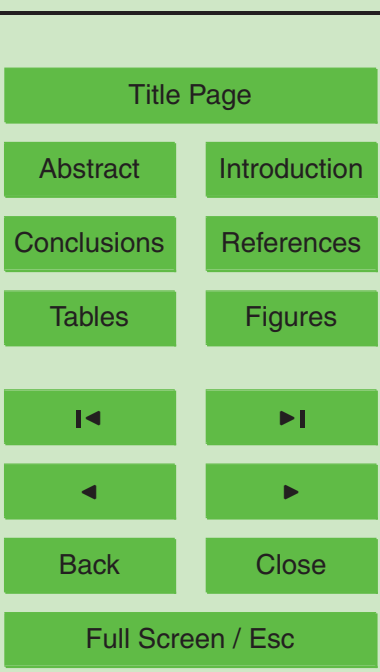

Printer-friendly Version

Fig. 1. Soil moisture sensor network installed at the Shale Hills Critical Zone Observatory. The transect of probes used in the case study is highlighted in solid black.

Full Screen / Esc

Interactive Discussion 

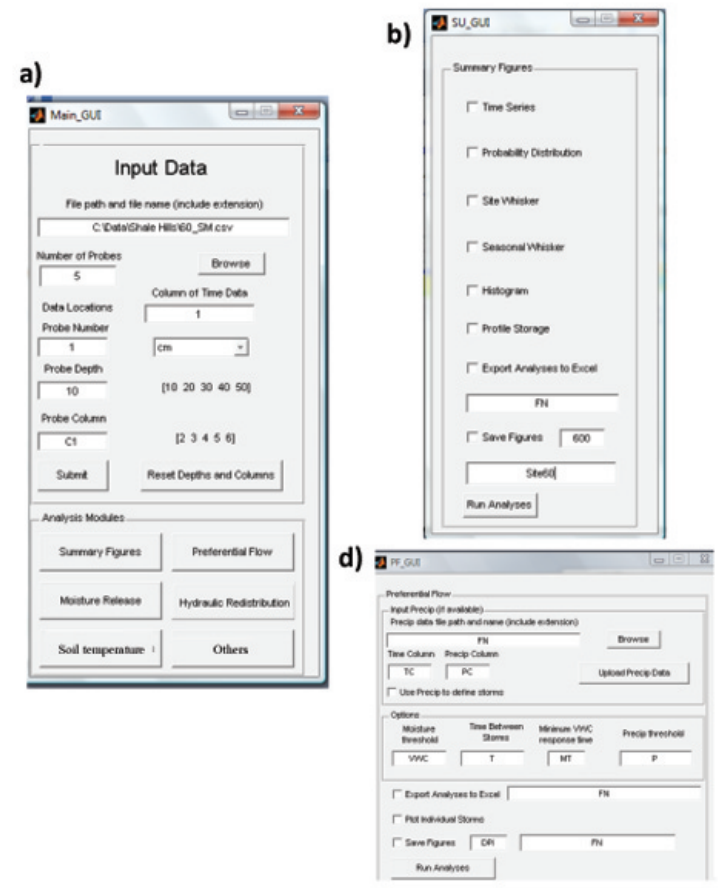

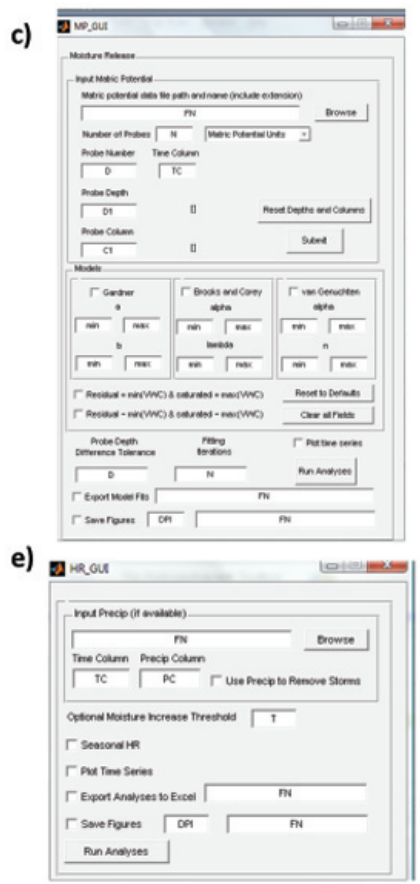

Fig. 2. Screen shots of the Graphical User Interface (GUI) developed in the Hydropedograph Toolbox: (a) main GUI with input data, (b) statistical summary module, (c) soil moisture release module, (d) preferential flow module, and (e) hydraulic redistribution module.

\section{HESSD}

$9,14231-14271,2012$

The Hydropedograph

Toolbox and its application

C. B. Graham and

H. S. Lin

\section{Title Page}

\section{Abstract}

Introduction

Conclusions

References

Tables

Figures

14

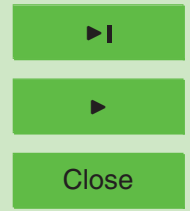

Back

Full Screen / Esc

Printer-friendly Version

Interactive Discussion 

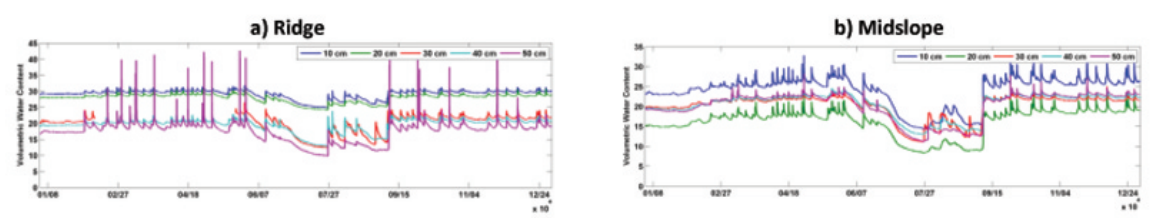

HESSD

9, 14231-14271, 2012

The Hydropedograph

Toolbox and its application
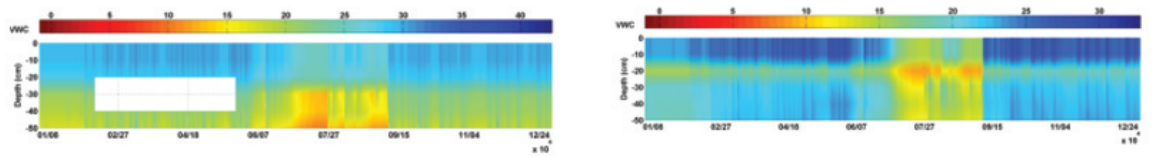

C. B. Graham and

H. S. Lin

c) Toeslope
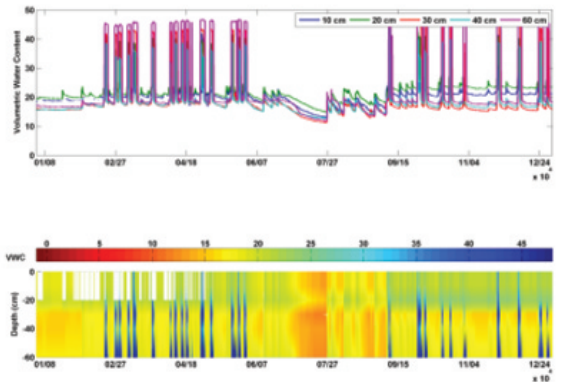

Fig. 3. Year 2011 time series of volumetric soil moisture content at multiple depths at (a) the ridge, (b) the midslope, and (c) the toeslope locations at the Shale Hills Critical Zone Observatory along the transect shown in Fig. 1. White spaces in the ridge and toeslope sites are a result of missing data due to equipment failure (a 70-day data gap at the $30 \mathrm{~cm}$ probe at the ridge site, and a series of small data gaps at the shallowest depth at the toeslope site). Note that color scheme and axes scale are not the same among the 3 sites, which depend on the data range from each individual site.

Title Page

Abstract Introduction

Conclusions

References

Tables

Figures

14

Back

Close

Full Screen / Esc

Printer-friendly Version

Interactive Discussion 
a) Ridge
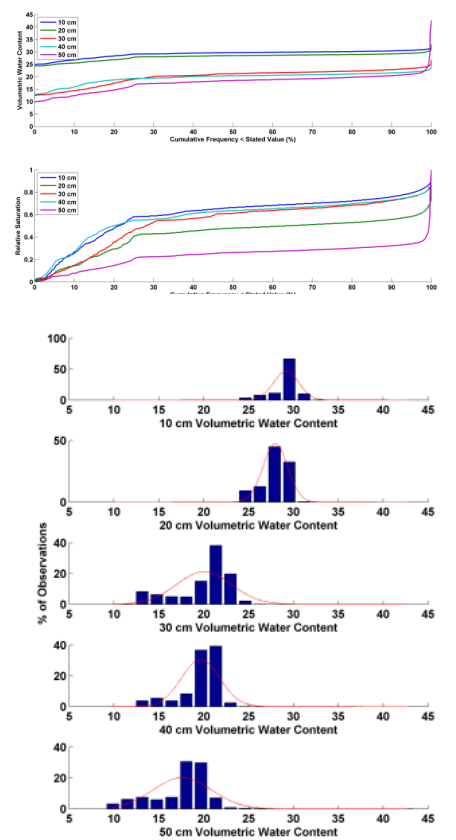

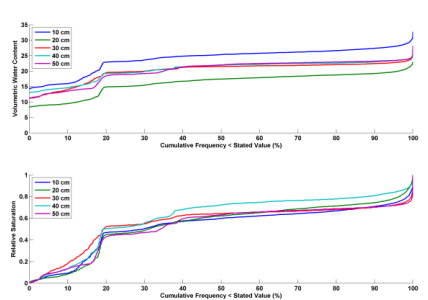

b) Midslope
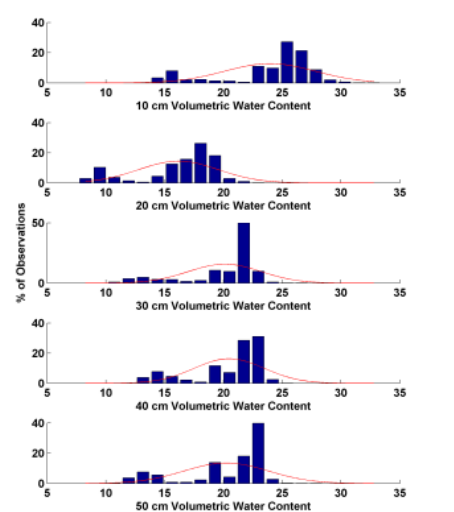

c) Toeslope
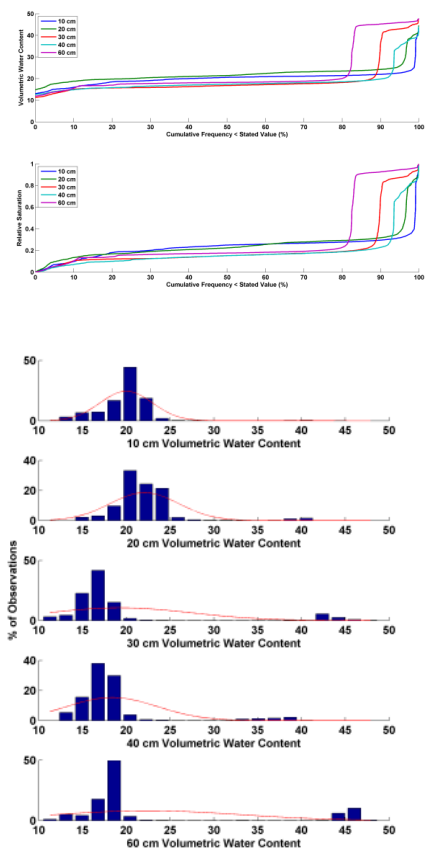

HESSD

9, 14231-14271, 2012

The Hydropedograph

Toolbox and its application

C. B. Graham and

H. S. Lin

Title Page

Abstract

Introduction

Conclusions

References

Tables

Figures

14

$>$ I

4

Back

Close

\section{Full Screen / Esc}

Printer-friendly Version

Interactive Discussion 


\section{HESSD}

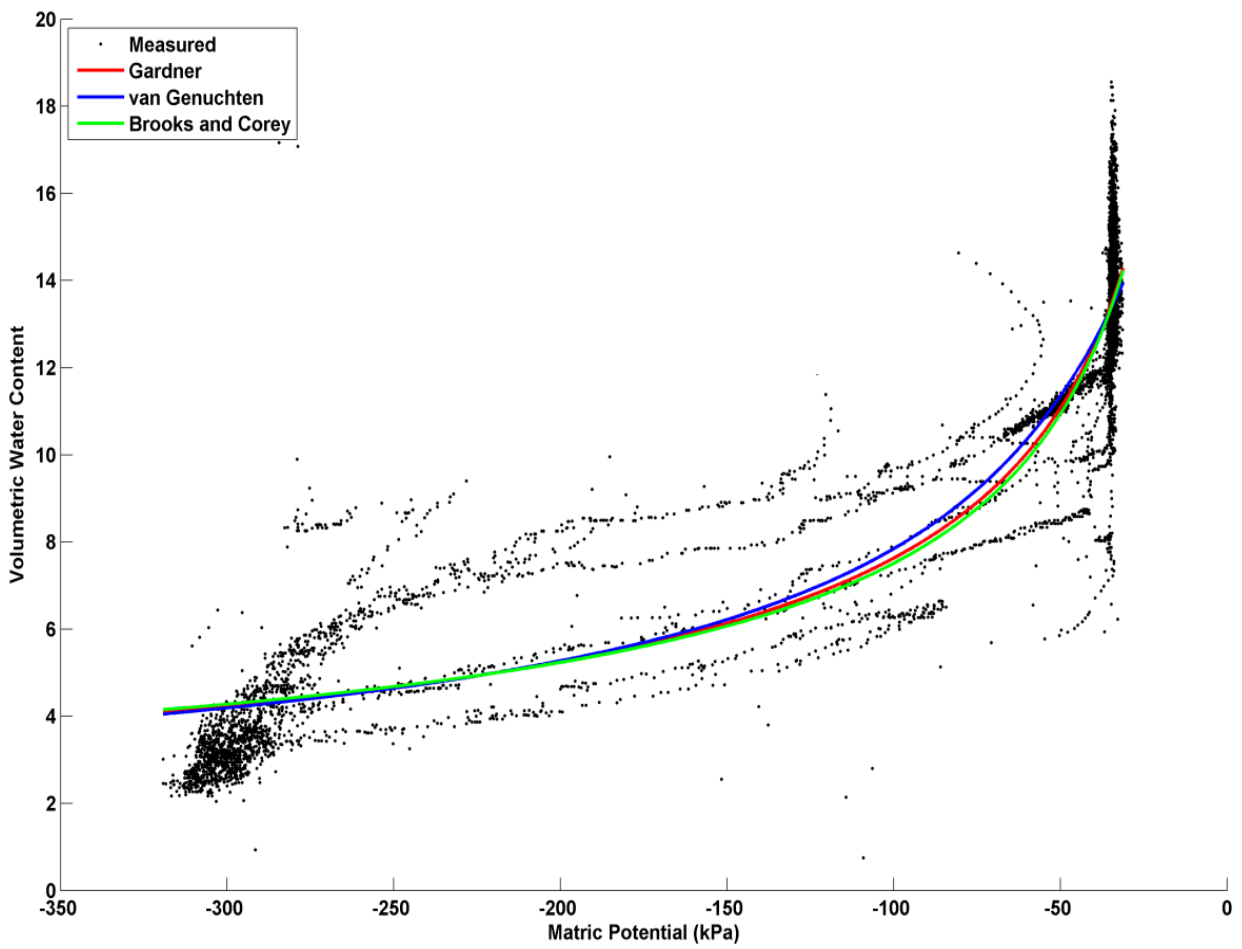

\section{9, 14231-14271, 2012}

The Hydropedograph Toolbox and its application

C. B. Graham and H. S. Lin

Title Page

Abstract

Conclusions

\section{Tables}

14

4

Back

\section{Introduction}

References

Figures

$\rightarrow 1$

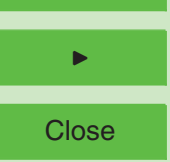

Full Screen / Esc

Printer-friendly Version

Interactive Discussion 
a)

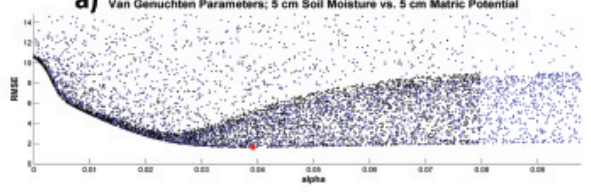

$$
\text { b) }
$$
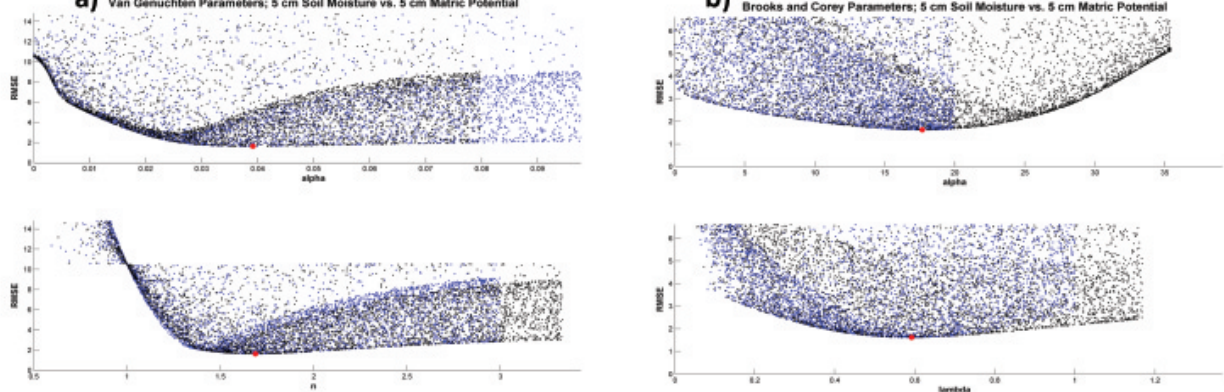

c)
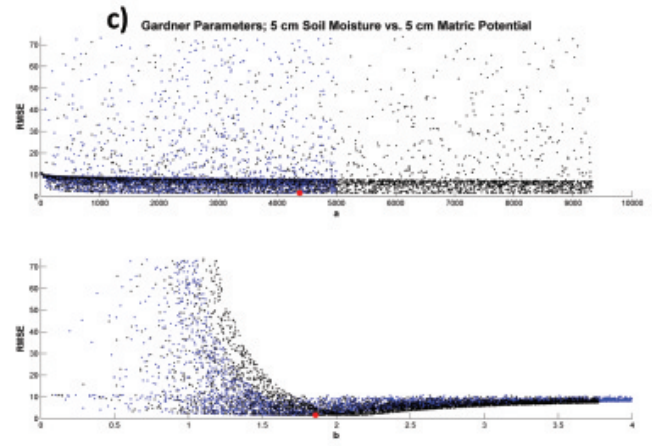

Fig. 6. Example dotty plots of parameters vs. model fit (root mean squared error) for the three models of soil moisture release curves: (a) van Genuchten, (b) Brooks and Corey, and (c) Gardner models. Red point indicates the best-fit model parameterization. Black dots indicate the input parameter range for the initial 5000 Monte Carlo runs, while blue dots indicate the automatically adjusted parameter ranges for the second 5000 runs.

\section{HESSD}

9, 14231-14271, 2012

The Hydropedograph

Toolbox and its application

C. B. Graham and

H. S. Lin

Title Page

\section{Abstract}

Introduction

Conclusions

References

Tables

Figures

14

4

Back

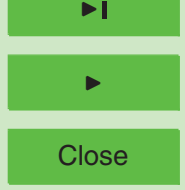

Full Screen / Esc

Printer-friendly Version

Interactive Discussion 

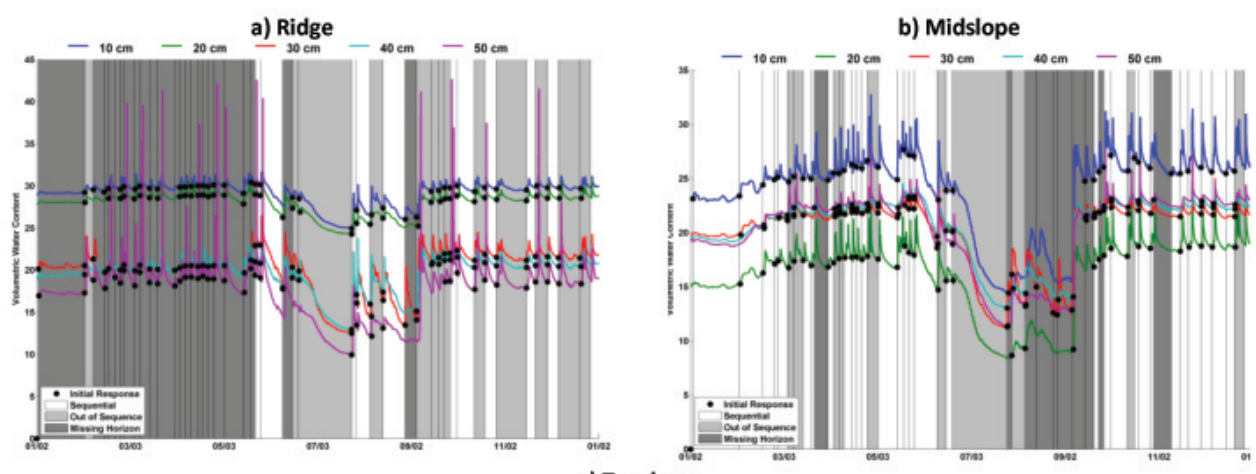

\section{HESSD}

9, 14231-14271, 2012

The Hydropedograph

Toolbox and its application

C. B. Graham and

H. S. Lin

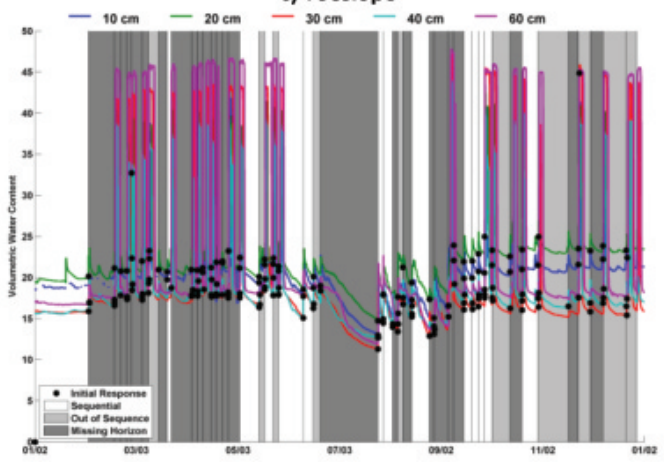

Title Page

Abstract

Conclusions

Tables

14

4

Back
Introduction

References

Figures

$\rightarrow 1$

$\checkmark$

Close

Fig. 7. Preferential flow occurrence at (a) the ridge, (b) the midslope, and (c) the toeslope locations at the Shale Hills along the hillslope transect indicated in Fig. 1. Shade of vertical lines indicates the type of preferential flow: light grey indicates out of sequence response to precipitation input, dark grey indicates interior horizons not responding while bounding horizons did (labeled in the Figure as missing horizon response), and white area indicates sequential flow (i.e., no preferential flow.)

Full Screen / Esc

Printer-friendly Version 

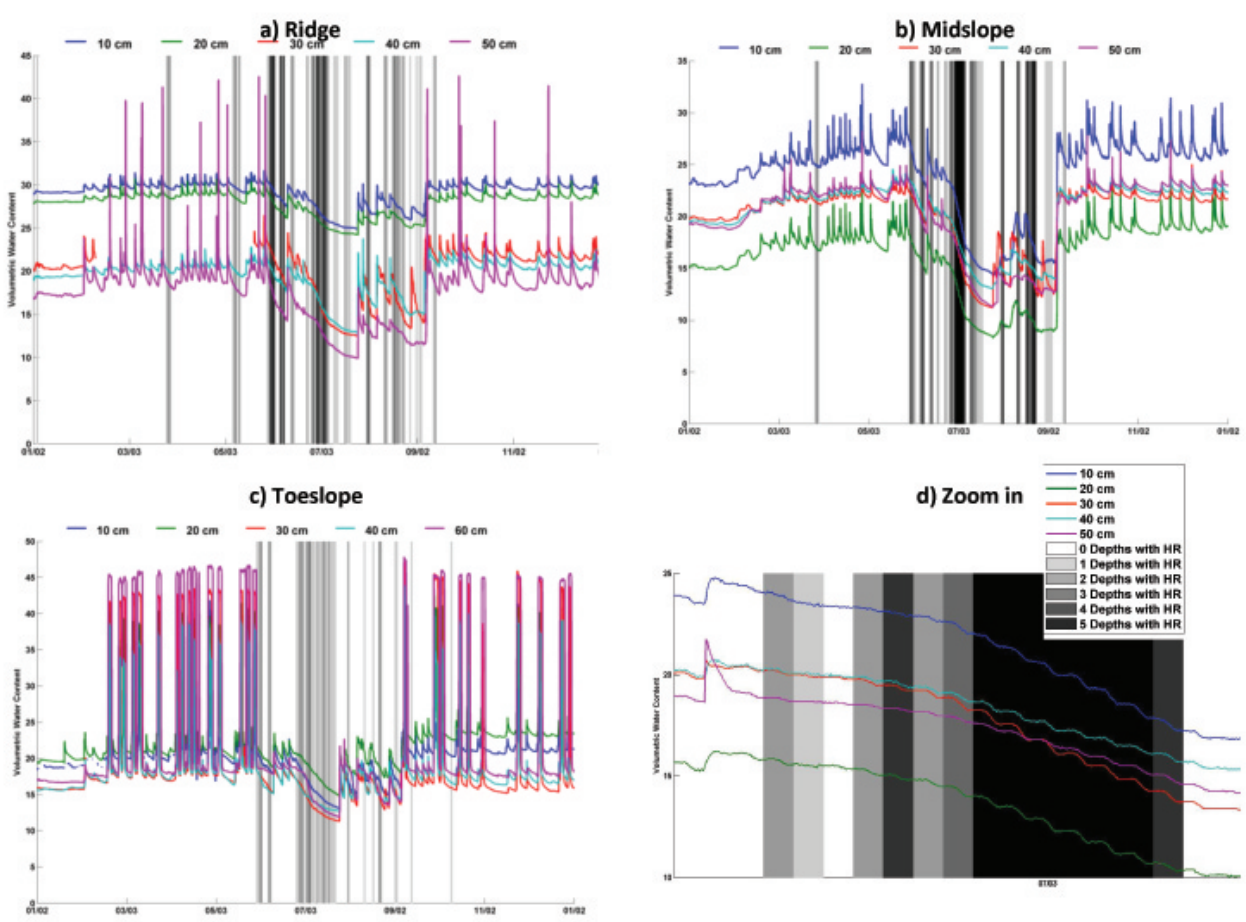

Fig. 8. Incidence of diel signals in the soil moisture at multiple depths at (a) the ridge, (b) the midslope, and (c) the toeslope locations at the Shale Hills along the transect indicated in Fig. 1. Shade of vertical lines indicates the number of soil horizons exhibiting diel signals (0 to 5 horizons as indicated by the gray ramp from white to black). Also shown in (d) is a zoom-in example of diel signals in soil moisture, with background color shade indicating the number of horizons showing diel fluctuations.

\section{HESSD}

$9,14231-14271,2012$

The Hydropedograph

Toolbox and its application

C. B. Graham and

H. S. Lin

\section{Title Page}

\section{Abstract}

Introduction

Conclusions

References

Tables

Figures

14

$\rightarrow 1$

4

Back

Close

\section{Full Screen / Esc}

Printer-friendly Version

Interactive Discussion 

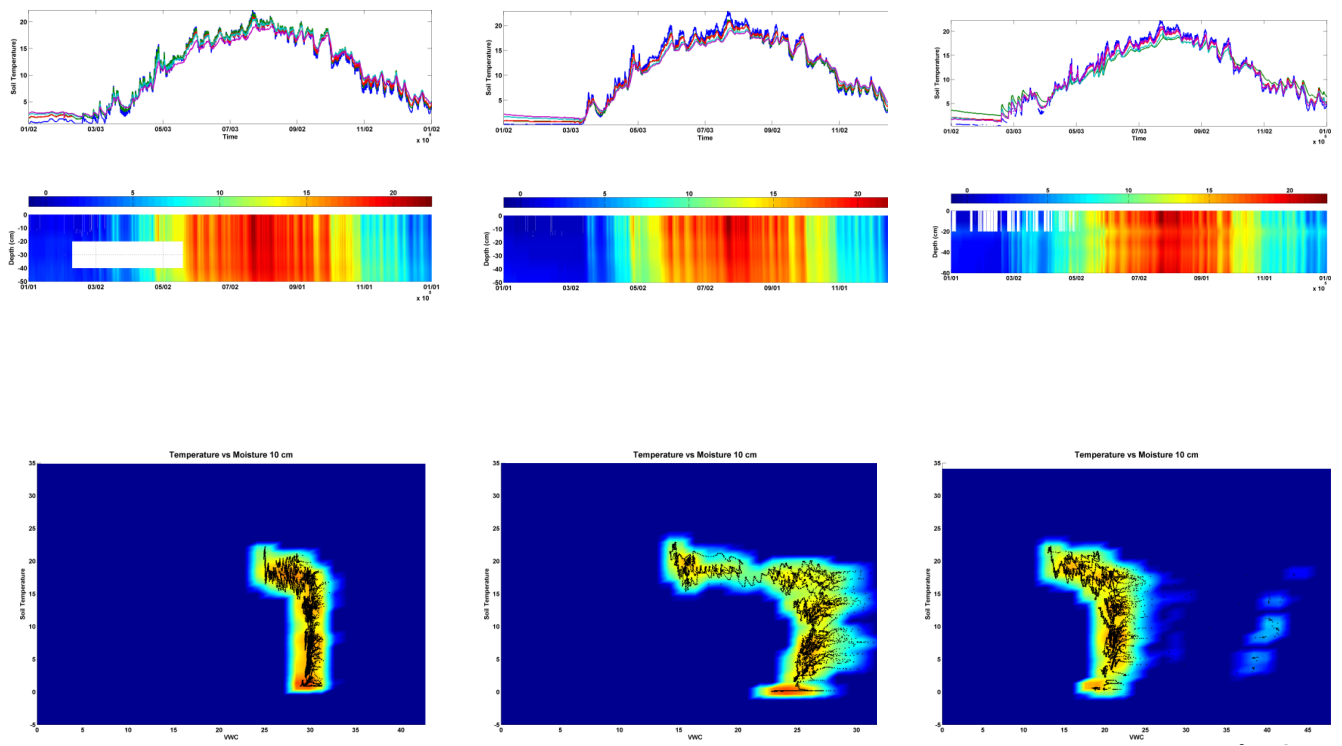

Fig. 9. Soil temperature time series at multiple depths at (a) the ridge, (b) the midslope, and (c) the toeslope sites at the Shale Hills along the hillslope transect indicated in Fig. 1. White spaces in the ridge and toeslope sites are a result of missing data due to equipment failure. The lower panel shows the plots of soil moisture vs. soil temperature at the same sites at $10 \mathrm{~cm}$ depth. Black dots indicate individual measurements, while color field indicates relative density of measurement points.
HESSD

$9,14231-14271,2012$

The Hydropedograph

Toolbox and its application

C. B. Graham and

H. S. Lin

Title Page

Abstract

Introduction

Conclusions

References

Tables

Figures

14

$>$ I

4

Back

Close

\section{Full Screen / Esc}

Printer-friendly Version

Interactive Discussion 


\section{HESSD}

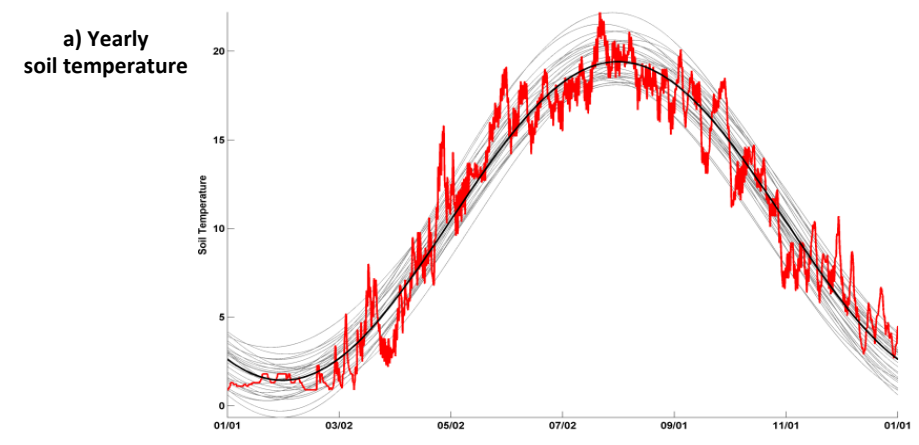

9, 14231-14271, 2012

b) Model fit of

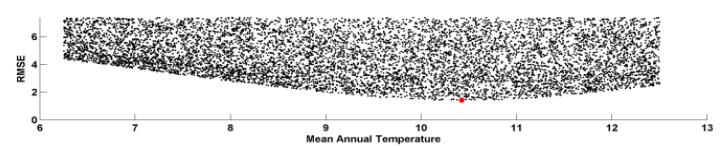

The Hydropedograph

Toolbox and its application

C. B. Graham and

H. S. Lin

soil temperature

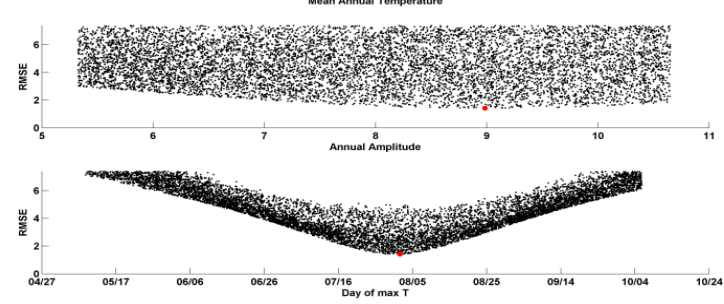

Title Page

Abstract

Introduction

Conclusions

References

Tables

Figures

14

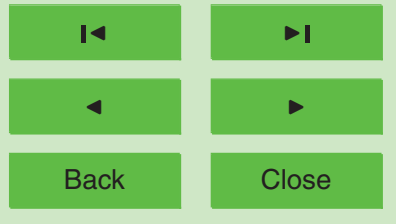

Fig. 10. (a) Yearly soil temperature data and various model fits for the $10 \mathrm{~cm}$ sensor at the ridge site. Grey lines indicate 20 representative calibrated models with acceptable fits, while dark black line indicates the best fit; (b) three calibrated temperature model parameters (mean annual temperature, annual temperature amplitude, and time of maximum temperature) plotted against model fits (root mean squared error). Red point indicates the best-fit model parameterization, and black dots indicate the input parameter range for the 10000 Monte Carlo runs.

Full Screen / Esc

Printer-friendly Version

Interactive Discussion 